\title{
Temporal Evolution and Geochemical Variability of the South-Pacific Superplume Activity
}

\author{
Alain Bonneville $e^{\mathrm{a}, *}$, Laure Dosso ${ }^{\mathrm{b}}$, Anthony Hildenbrand ${ }^{\mathrm{c}}$ \\ ${ }^{a}$ Institut de Physique du Globe de Paris / Centre National de la Recherche Scientifique \\ 4, Place Jussieu, 75252 Paris Cedex 05, France \\ ${ }^{\mathrm{b}}$ Centre National de la Recherche Scientifique \\ UMR 6538 \\ IFREMER, BP 70, 29280 Plouzané, France \\ ${ }^{\text {c }}$ Centre National de la Recherche Scientifique, Laboratoire Géochronologie, \\ Université Paris-Sud, 91405 Orsay, France
}

* Corresponding author.

Tel. : +33 1442768 94; Fax : +33 144279969 ; E-mail : bonneville@ipgp.jussieu.fr

Keywords : mantle plume, South Pacific Superswell, geochemical sources, seamount ages, Cook-Austral, hotspot

Bonneville, A., L. Dosso and A. Hildenbrand, Temporal Evolution and Geochemical Variability of the South-Pacific Superplume Activity, Earth Plan. Sc. Letts, 244, 251-269, doi:10.1016/j.epsl.2005.12.037 , 2006.

Received 24 November 2004; received in revised form 19 July 2005;

accepted 7 December 2005

Available online 21 February 2006, Editor: B. Wood 


\begin{abstract}
We are presenting a new set of K/Ar ages and geochemical analyses obtained on deep-sea samples dredged in 1999 on several seamounts of the Cook-Austral volcanic chains in the Pacific Ocean. The new geochemical results, together with published data on island samples, allow us to reveal a time evolution of the mantle source composition as well as an increase in geochemical variability of the superplume responsible for the regional South Pacific Superswell. Three identified volcanic stages of 58-40 Мa, 33-20 Ma and 20-0 Мa are identified with signatures of mantle reservoir composition varying from close to $\mathrm{C}$ to $\mathrm{N}$ MORB-types and C/HIMU-type respectively. Using a geodynamic reconstruction for the most recent volcanic period, from 20 Ma to present, three hotspot tracks are needed to explain the several volcanic episodes observed within the limited geographical area of the central part of the Cook-Austral chains. At the scale of a single volcano, different magmatic phases can also be identified with different ages and geochemical signatures, emphasizing the importance of structural control, either crustal or lithospheric, in the location of the magmatic outputs. These observations, taken together, are in good agreement with a model where each hot spot could sample a small volume of the large very heterogeneous plume responsible for the regional South Pacific Superswell.
\end{abstract}

\title{
1 - Introduction
}

The Cook-Austral volcanic chain is located on the southern part of the Pacific Plate, in a region of anomalous shallow seafloor known as the South Pacific Superswell [1]. This region of anomalously high bathymetry is also geochemically anomalous and known as the location of the South Pacific Isotope and Thermal Anomaly, SOPITA [2]. The Cook-Austral chain signature, based essentially on island sampling, is often attributed to a "HIMU"-type mantle source characterized by Mid-Ocean Ridge Basalt (MORB) - like Sr isotopic ratios and highly radiogenic $\mathrm{Pb}$ isotopic ratios (see review in [3]). Deep-sea samples of the Austral chain were collected during the ZEPOLYF2 cruise that took place in July 1999 between $22^{\circ} \mathrm{S}$ and $28^{\circ} \mathrm{S}$ latitude and $143^{\circ} \mathrm{W}$ and $155^{\circ} \mathrm{W}$ longitude (Figures 1 and 2). Geophysical data including multibeam bathymetry, acoustic imagery, seismic reflection, gravity and magnetic data were also collected. 31 seamounts were mapped and 24 dredges recovered volcanoclastic sediments, altered and fresh pillow basalts, hyaloclastites and ferromanganese crusts. We present here geochemical data obtained on 17 samples selected from these dredges on the basis of their petrographic freshness. Two additional basaltic samples were included in this study (PLD07 and PLD09, Figure 2); they were collected in March 1998 during the POLYDRAG1 cruise (chief scientist, A. Bonneville) on the Tarava Seamount chain located between the Society island and the Austral islands chains [4]. This collection of submarine basalt samples has been dated by K/Ar techniques. These new geochemical results, together with published data on island samples, allow us to explore the link between the volcanic activity observed at the Earth surface and deep mantle processes.

\section{2 - Geological setting}

The Cook-Austral chain extends from the island of Aitutaki $\left(140^{\circ} \mathrm{W}, 29^{\circ} \mathrm{S}\right)$ to the active submarine volcano Macdonald $\left(160^{\circ} \mathrm{W}, 19^{\circ} \mathrm{S}\right)$ in a band more than $2200 \mathrm{~km}$ long and $240 \mathrm{~km}$ wide, oriented $\mathrm{N} 115^{\circ} \mathrm{E}$ (Figures 1 and 2). The chain is composed of several dozens of seamounts and of 11 islands and 2 atolls with little area above sea level $\left(70 \mathrm{~km}^{2}\right.$ for the largest island). The Austral Fracture Zone (FZ) cuts the chain between the islands of Tubuai and Raivavae. Although oriented roughly in the direction of present Pacific plate motion ( 11 $\mathrm{cm} . \mathrm{y}^{-1}$ along a $\mathrm{N} 115^{\circ}$ direction), the spatial and temporal pattern of both the aerial and submarine volcanoes is rather complex.

The age of the oceanic crust along the chain ranges from about 39 Ma to 84 Ma [5] (Figure 2). Several K/Ar or Ar/Ar ages are available on almost all the islands of the Cook-Austral chain 
and on seamounts in the Taukina and Ngatemato seamount chains [6], but to date no seamount in the northern Austral region has been dated yet.

The particular geometry and morphology of the chain have suggested so far two distinct but parallel alignments [7]. In 1997, McNutt et al. [6] determined the existence of two additional chains of volcanoes near the active Macdonald seamount at the southeast end of the chain, 2034 m.y. older than the Macdonald volcanism. Both recent and old ages recorded on Aitutaki, and Rurutu islands basaltic samples [8,9] suggest the existence of two other hotspots (Rarotonga and Rurutu) and in 2002, Bonneville et al. [10] proposed that the most recent volcanic stage of Rurutu be attributed to Arago Seamount, a very shallow seamount located $120 \mathrm{~km}$ east-southward of Rurutu and sampled during the ZEPOLYF2 cruise. To summarize up to 6 distinct hotspot tracks have been identified so far : from northwest to southeast, Rarotonga, Arago, Tubuai, Macdonald, Taukina and Ngatemato of which three are probably still active, Rarotonga, Arago and Macdonald.

\section{3 - K-Ar dating of the dredged samples}

During the ZEPOLYF2 cruise, 24 successful dredges were performed (Figure 2). Most of them were on lava flows covering the seamount slopes and most of them are very altered. They are classical pillow basalts with a major glassy phase in which the microlitic content increases towards the core. They contain some early crystallized phenocrysts, often altered, with inherited radiogenic Argon in various proportions. They also contain secondary mineral phases like zeolites due to fluid circulation. Moreover, right or immediately after the emplacement of the flow, the matrix is devitrified yielding to formation of mainly clay minerals.

Some basaltic samples have a very low $\mathrm{K}$ and high Ca content. Despite the low $\mathrm{K}, \mathrm{K} / \mathrm{Ar}$ method remains the most appropriate one to date basalts younger than $60 \mathrm{Ma}$, if applied to a mineral phase representative of the lava flow emplacement [11-13]. Our samples contain different mineral assemblages corresponding to the successive stages of the lava history: (1) evolution in the magma chamber, (2) solidification on the seafloor, (3) hydrothermal circulation and finally, (4) in situ alteration. The chronometer is, thus, very questionable, and the whole rock dating of such lavas is unsuitable. Even though ${ }^{40} \mathrm{Ar} /{ }^{39} \mathrm{Ar}$ technique allows a distinction between phases to be made using a step heating procedure on whole rock grains [13], we chose to work with a single phase technique. The selection of the correct phase is critical to get the age of the lava flow, i.e. stage (2). This phase in our samples is generally microlitic plagioclase and occasionally nepheline. The rapid cooling of the pillow-basalt, however, limits the size of these microlites to some tens of microns. This small size precludes the use of the ${ }^{40} \mathrm{Ar} /{ }^{39} \mathrm{Ar}$ dating technique because of the recoil of ${ }^{39} \mathrm{Ar}$ during the neutron activation. Moreover, the very high Ca content of plagioclase restricts the applicability of ${ }^{40} \mathrm{Ar} /{ }^{39} \mathrm{Ar}$ dating technique, especially for younger rocks for which the radiogenic ${ }^{40} \mathrm{Ar}$ content is very low. Considering these limitations, we decided to use a $\mathrm{K}$-Ar dating technique devoted to detect very low radiogenic ${ }^{40} \mathrm{Ar}$ contents: the Cassignol technique [12, 14]. This technique has been previously applied successfully to submarine basalts from various settings, and yielded ages coherent with the stratigraphic and geodynamic constraints [4].

\section{Sample preparation}

The inner part of the pillows is systematically used for dating. A specific technique is applied to extract the pure microlitic plagioclase phase when preserved. First, the rocks are crushed and sieved to a 125 to $500 \mu \mathrm{m}$ size fraction. Heavy liquids are used to remove all phenocrysts and to select the pure microlitic groundmass. Then, the groundmass is crushed again to a smaller size such as to isolate pure plagioclase microlites (generally around 30 to $50 \mu \mathrm{m}$ ). Finally, a magnetic separator is used to separate pure plagioclase from the altered glass and other microlites. The different microlitic sizes extracted from the various samples are summarized in Table 1. When possible, different mineral phases are isolated: plagioclase microlites, plagioclase phenocrysts, nepheline (Figure 3) and groundmass. They constitute independent phases which are important to check for internal consistency of a given sample. 
This is illustrated in pillow-lavas DR07B and DR24-02 (Figure 4) for which both plagioclase crystals $(125-250 \mu \mathrm{m})$ and microlites $(30-50 \mu \mathrm{m})$ have been separated and analyzed.

Note that the double separation is not necessary for the freshest samples DR02, DR04 and DR14-03, because their groundmass is fresh and well preserved. Finally, special attention has been given to the highly under-saturated glassy pillow-lava DR07 which contains small cubic crystals of nepheline. For this sample, dating has been done both on this particularly K-rich phase and on the preserved glassy groundmass, since the separated nepheline quantities were small.

Most samples have been dated twice and Table 1 summarizes the results :

- for samples with duplicate dates on the same mineral phase (DR01, DR02, DR04, DR05, DR14, DR16, DR18, DR24), ages are perfectly reproducible;

- for DR23 and DR07B, a slight discrepancy can be observed between the dating made on two different phases: (1) microlites and (2) plagioclase phenocrysts;

- for DR07, the dating made on the nepheline phase and on the groundmass are different (by $0.2 \mathrm{Ma}$ ) but they are coherent. Both give a very recent age for the sample; however the age based on the nepheline phase is preferred because of the higher $\mathrm{K}$ content and of the lower Ar contamination level.

In a few cases very different ages are obtained within a single dredge. This indicates that different volcanic episodes have been sampled along the dredge haul. This can be seen in particular for DR07 and suspected for DR14 and DR23 (see below).

A large range of ages, between $0.23 \mathrm{Ma}$ and $58.1 \mathrm{Ma}$, is observed with a maximum uncertainty of $2 \%$. These new results bring important constraints to the geodynamical evolution of this region as further discussed in sections 5 and 6.

\section{4 - Geochemical analytical techniques and results}

Major, trace element and isotope data are presented in Table 2.

\section{Sample preparation}

Aboard the ship, all samples are crushed to centimeter size fragments. Pieces of glass or chips from the inner part of lava flows or pillow lavas are handpicked to avoid (1) Fe-Mn coatings, which could be a potential source of $\mathrm{Pb}$ and $\mathrm{Nd}$ contamination (2) altered surfaces which could have an effect on $\mathrm{Sr}$ isotope compositions. All samples (either glasses or rock chips) are washed in an ultrasonic bath of $2 \mathrm{M} \mathrm{HCl}$, followed by double quartz distilled water before further crushing in an agate mortar for major and trace element analysis. For $\mathrm{Sr}$ and $\mathrm{Nd}$ isotope analyses, the powder is further leached to remove seawater alteration with $0.1 \mathrm{~N} \mathrm{HCl}$ for a few minutes in an ultrasonic bath and rinsed in deionized water. The Sr-Nd separations are done according to the procedure described in [15]. Pb separation is performed on a separate aliquot of the powdered sample leached with $6 \mathrm{M} \mathrm{HCl}$ at $140^{\circ} \mathrm{C}$ for an hour and rinsed up to 6 times with deionized water and dried. Such a procedure gives reliable $\mathrm{Pb}$ isotope ratios on whole rock powders as shown by Regelous et al [16]. Sr and $\mathrm{Nd}$ ratios were measured on a Finnigan MAT261 multicollector instrument, in dynamic mode and were corrected for mass fractionation to a value of 8.375209 for ${ }^{88} \mathrm{Sr} /{ }^{86} \mathrm{Sr}$ and 0.721903 for ${ }^{146} \mathrm{Nd} /{ }^{144} \mathrm{Nd}$. Standards NBS987, La Jolla and JNdi-1 analyzed during the sample measurement period gave values of $0.71025 \pm 2(n=20), 0.511852 \pm 10(n=34)$ and $0.512104 \pm 4$ $(\mathrm{n}=15)$. High-resolution $\mathrm{Pb}$ analyses were made using the double spike technique with the calibrated Southampton-Brest 207/204 spike [17]. Replicate analyses of the $\mathrm{Pb}$ isotope standard NBS981 gave an average of $16.9431 \pm 33,15.5001 \pm 39,36.7317 \pm 11(2 \mathrm{sd}, \mathrm{n}=28)$ for ${ }^{206} \mathrm{~Pb} /{ }^{204} \mathrm{~Pb},{ }^{207} \mathrm{~Pb} /{ }^{204} \mathrm{~Pb}$ and ${ }^{208} \mathrm{~Pb} /{ }^{204} \mathrm{~Pb}$ respectively. $\mathrm{Pb}$ blanks were about $30 \mathrm{pg}$ and thus negligible.

\section{Major Elements}

Most samples are alkali basalts and basanites (Figure 5). Some samples have severe alteration features such as a high loss of ignition. DR14-4 is a basaltic breccia rich in clinopyroxenes.

\section{Trace Elements}


The data are presented in Figure 6. The rare earth diagrams are extended to include Th, Nb, $\mathrm{Ta}, \mathrm{Zr}$, Hf and Y. The concentrations are normalized to the primitive mantle values [18], shown in parenthesis after the element name, in Table 2. It is important to note that the samples have been affected by seawater alteration. During such low temperature alteration, however, $\mathrm{Nb}$, Ta, $\mathrm{Zr}$, and Hf remain in the basalt whereas $\mathrm{Y}$ and the trivalent REE are partially removed [19]. Therefore concentration ratios of elements such as $\mathrm{Zr}, \mathrm{Nb}, \mathrm{Hf}$ and $\mathrm{Ta}$ are considered to be insensitive to alteration. As described above in the sample preparation, more efficient alteration removal has been applied to samples for isotope analyses.

Most samples have light REE enriched patterns, like typical intraplate volcanic lavas (Figure 6). In detail, however, there seems to be a temporal evolution of the sample patterns. Sample DR14-4, the clinopyroxene rich sample is not included in this discussion as, due to its low $\mathrm{K}$ content, it could not be dated and its extended REE pattern is dominated by clinopyroxenes and thus does not represent the basalt. The oldest group of samples (40-58 Ma) has enrichment in light REE (LREE) relative to heavy REE with $(\mathrm{La} / \mathrm{Sm})_{\mathrm{N}}$ between 1.0 and 4.2. The second group (20-33 Ma) has LREE depleted patterns such as found in N-MORB (Normal Mid-Ocean Ridge Basalts) with $(\mathrm{La} / \mathrm{Sm})_{\mathrm{N}}$ between 0.7 and 1.4. The REE patterns of transitional basalts DR20-2 and DR23-2 have negative Nb anomalies and fractionated Nb-Ta and $\mathrm{Zr}$-Hf ratios. Both features are similar to those of depleted MORB basalts. Finally, the youngest group (0-20 Ma) includes LREE patterns as commonly described in intraplate volcanic samples. It shows the largest enrichments and concentration variations of all groups with $(\mathrm{La} / \mathrm{Sm})_{\mathrm{N}}$ between 2.2 and 5.0. DR23-3, unfortunately too altered to be dated, is plotted with the youngest group on the basis of its isotopic composition. Although such trace element groupings seem tentative, the isotope data also show similar distinction as is discussed below.

\section{Isotopes}

The isotopic data are not corrected for post-emplacement decay because the $\mathrm{Rb} / \mathrm{Sr}$ (as can be estimated from the extended REE patterns) and $\mathrm{Sm} / \mathrm{Nd}$ ratios are small enough that changes in $\mathrm{Sr}-\mathrm{Nd}$ isotopic ratios are negligible over the considered time period. In the same way, we will assume a negligible evolution of $\mathrm{Pb}$ isotopic compositions. The data are therefore compared directly to available data from the literature on samples collected in the same area including Pacific mid-ocean ridge basalt data. All Sr-Nd data from the literature have been normalized to the same standard values of 0.71025 for NBS987 and 0.511852 for La Jolla.

In all diagrams (Figures 7 to 9), the most remarkable feature of the new data is heterogeneity. However it should be remembered that this data set not only includes samples from a wide geographical area but also from a large temporal range (from $58 \mathrm{Ma}$ to present). The values range from very depleted $(\mathrm{Sr}, \mathrm{Pb}) \mathrm{MORB}$ values found in basalts south of the Austral FZ between Rapa and Raivavae (DR18-DR20-DR23) to very radiogenic values. Such depleted MORB-type values ( $\mathrm{Sr}$ isotopic ratio as low as 0.70258 ) in intraplate volcanic samples have not been previously reported. The most radiogenic Sr value is found south of the Austral FZ in a basaltic sample (0.70434 -DR14-3). This value is similar to those found in Rarotonga and Aitutaki samples (Figure 7). Intermediate Sr-Nd values include HIMU-type values similar to those found for Tubuai and Mangaia basalts (DR01-DR04-DR21). Large Sr-Nd isotopic heterogeneity is found within single dredges such as DR14 and DR23. DR14-3 has extreme Sr-Nd compositions towards EM-type mantle sources whereas DR14-4 has Sr-Nd compositions that are close to the HIMU field of compositions. DR23-2 has Sr-Nd isotopic characteristics of Pacific MORB samples whereas DR23-3 has an isotope composition similar to the young volcanic lavas from Rurutu. Examination of Pb-Pb diagrams (Figures 8 and 9) reinforces these observations. The ${ }^{206} \mathrm{~Pb} /{ }^{204} \mathrm{~Pb}$ isotopic compositions display a very wide range, from 17.59 to 20.87. We note that the most depleted samples located on the edge of the Pacific MORB field, have higher ${ }^{207} \mathrm{~Pb} /{ }^{204} \mathrm{~Pb}$ and ${ }^{208} \mathrm{~Pb} /{ }^{204} \mathrm{~Pb}$ ratios than the Northern Hemisphere Regression Line, (NHRL), whereas the most radiogenic samples are located below the NHRL, and are of HIMU-type within the Tubuai-Rimatara field (DR04-2). Other samples have $\mathrm{Pb}$ isotopic ratios which vary between Pacific MORB sample values to values 
typical of those found in Rarotonga-Aitutaki, Macdonald-Raivavae and Rurutu island volcanics (Figures 8 and 9a). In Figure $9 \mathrm{a},{ }^{208} \mathrm{~Pb} /{ }^{206} \mathrm{~Pb}$ is plotted against ${ }^{207} \mathrm{~Pb} /{ }^{206} \mathrm{~Pb}$. We note that the extreme isotopic heterogeneity that was pointed out within a single same dredge is confirmed in $\mathrm{Pb}-\mathrm{Pb}$ systematics both for DR14 and DR23. Pb-Pb diagrams (Figures 8 and 9a) suggest that the whole sample set might be divided into three groups according to age: $0-20$ Ma, 20-33 Ma and 40-58 Ma, consistent with the classification based on the extended rare earth patterns presented above. The youngest group, the most radiogenic in $\mathrm{Pb}$, includes samples with enriched trace element patterns only. The 20-33 Ma age group has MORB isotopic characteristics and includes samples with slightly enriched to depleted XREE patterns. Finally, the 40-58 Ma group includes only trace element enriched samples.

These groups are also clearly separated when a key trace element ratio that is diagnostic of mantle source composition such as $\mathrm{Th} / \mathrm{Ta}$ (insensitive to variable degrees of partial melting) is combined with $\mathrm{Pb}$ isotopic information such as ${ }^{206} \mathrm{~Pb} /{ }^{204} \mathrm{~Pb}$ (Figure 9b) or the distance to the reference line NHRL, $\Delta^{207} \mathrm{~Pb} /{ }^{204} \mathrm{~Pb}$ (Figure 9c). DR14-3, dated at $8.8 \mathrm{Ma}$, is outside either group as is also shown by its peculiar Nd-Sr isotopic characteristics. A sample with unusual isotopic ratios (Nd composition of 0.51278) was also found in Rurutu island (74-394) and ignored in the discussion [20]. DR14-4, the clinopyroxene rich basaltic breccia, could not be dated but its geochemical characteristics suggest that it belongs to the 20-33 Ma age group. Samples from a single dredge (DR23) show a very large heterogeneity: ${ }^{206} \mathrm{~Pb} /{ }^{204} \mathrm{~Pb}$ ratios vary from 18.0 to 20.3 for DR23-2 and DR23-3 respectively. However DR23-2 is a glassy sample that has been dated at $33 \mathrm{Ma}$ whereas no age is available for DR23-3. These two samples from the same dredge most likely belong to different stages of volcanism. The isotopic characteristics of DR23-3 place it rather in the 0-20 Ma group of samples.

In a $\mathrm{Nd}$ vs. Pb isotopic diagram (Figure 10), the different age groups can also be identified.

\section{5 - Discussion}

The new geochemical data presented in this paper, based on sampling of seamounts of different ages, clearly illustrate the large heterogeneity of mantle sources at the regional scale of the Cook-Austral island chain between $58 \mathrm{Ma}$ and present.

\section{Temporal evolution of mantle source composition}

This large mantle heterogeneity is seen in isotopes as well as in trace elements. However, the data set appears to be coherent in terms of age, isotope compositions and XREE data :

- Between 58 and $40 \mathrm{Ma}$, the tapped source presents enriched XREE patterns with a small variation in ${ }^{206} \mathrm{~Pb} /{ }^{204} \mathrm{~Pb}(18.4-9.0)$ and with a range in ${ }^{143} \mathrm{Nd} /{ }^{144} \mathrm{Nd}$ from 0.51280 to 0.51295 . This area of the isotopic field is close to what has been referred to as the Common mantle component "C" zone [21] or FOZO (FOcus ZOne) [22] and could represent the material found between the enriched blobs in a "marble cake" mantle.

- Between 33 and $20 \mathrm{Ma}$, the isotopic field describing the source has rather depleted characteristics with almost constant MORB-type Nd values around 0.5131 whereas ${ }^{206} \mathrm{~Pb} /{ }^{204} \mathrm{~Pb}$ values range from 17.6 to 18.2 . Samples in this age group present depleted to slightly enriched extended rare earth patterns.

Both groups are characterized by $(\mathrm{La} / \mathrm{Sm})_{\mathrm{N}}$ between 0.7 and 4.2 and $\mathrm{Th} / \mathrm{Ta}$ ratios between 0.7 and 0.9 .

- Between $20 \mathrm{Ma}$ and present time, the geochemical heterogeneity is larger. The rare earth patterns are the most enriched of all three age groups with $(\mathrm{La} / \mathrm{Sm})_{\mathrm{N}}$ between 2.2 and 5.0 and $\mathrm{Th} / \mathrm{Ta}$ ratios between 1 and 1.9. Isotopically, it is also the most heterogeneous group with ${ }^{206} \mathrm{~Pb} /{ }^{204} \mathrm{~Pb}$ ranging from 19.0 to 20.9 and ${ }^{143} \mathrm{Nd} /{ }^{144} \mathrm{Nd}$ ranging from 0.51269 to 0.51293 . In terms of mantle source-types, C to HIMU-types are found. Local heterogeneity can also be observed at the dredge scale, like in DR14 where DR14-3, the only dated sample, and DR14-4 have widely different isotopic 
ratios. Most likely these two samples are from two different volcanic stages as already pointed out above in the case of DR23.

To summarize, from $58 \mathrm{Ma}$ to $40 \mathrm{Ma}$, the mantle source is close to C type, between $33 \mathrm{Ma}$ and $20 \mathrm{Ma}$, the mantle source is of N-MORB type, between $20 \mathrm{Ma}$ and present time, the source could be a mixture between $\mathrm{C}$ and HIMU type sources. During this last time period, hot spot tracks can be reconstructed.

\section{Hotspot track reconstruction (0-20 Ma)}

Three hotspot tracks have been recognized using a method coupling geodynamical reconstruction and the new $\mathrm{K} / \mathrm{Ar}$ ages obtained on these samples added to the already available ages on islands.

To reconstruct the apparent path followed by a hotspot on the seafloor, we have moved the hotspot present location back in time by using the set of stage poles proposed by Wessel and Kroenke [23]. This data set represents the most updated synthesis for the absolute Pacific plate motion since $145 \mathrm{Ma}$. However, for the last interval (0-3 Ma), we have chosen to use the pole previously proposed by Yan and Kroenke [24]. The apparent hot spot tracks are determined for the past 20 m.y. with this set of absolute stage poles (Figure 11). If we use a $100-\mathrm{km}$-wide track as representative of the zone of influence of a given hotspot source, we clearly see that the Macdonald hotspot could not have generated the northern Austral Islands. Furthermore, the Macdonald hotspot track fits well with the 19 Ma age of Mangaia and with the K-Ar age of 8.8 Ma obtained on the seamount ZEP2-19 (DR14-3). On the other hand, the northern Austral Islands can be well explained by a hotspot source that probably stopped producing magma at Raivavae ca. 6.5 Ma. This solution has also the advantage of linking together islands with isotopic signatures clearly different from those of Macdonald. President Thiers bank to the east is a guyot and probably much older. Finally, by using the same stage poles, the Arago track is drawn. It fits quite well with Rurutu and Cook Island ages. Note that volcanoes are often not located along the track axis, which we think emphasizes the importance of lithospheric control over a change in the mantle source location.

\section{Mantle source variation along hotspot track}

When looking at individual hotspot tracks in the last 20 Ma determined above and identified in Figure 10 with different colors, one can reveal specific characteristics of each of the sources with all tracks including " $\mathrm{C}$ " compositions. The three volcanic tracks are from north to south: (1) the Raivavae track (green line and symbols) from Raivavae Island (6.5 Ma) to Rurutu Island and nearby seamounts (12 Ma), (2) the Arago track (blue line and symbols) from Arago seamount (0.2 Ma) to Atiu Island (8 Ma) and (3) the Macdonald track (red line and symbols) from Macdonald seamount (0 Ma) to Mangaia (19 Ma).

(1) The Raivavae track extends from Raivavae-type (6.5 Ma) to old Rurutu type (12 Ma) towards the HIMU Mangaia-type. Tubuai Island and DR04-2, a sample dredged on a seamount eastward of Rurutu Island, belong to the old Rurutu field. DR07B, a sample dredged on Arago seamount, and dated at 8.2 Ma, has a Raivavae signature as well as DR22, a sample dredged on the northeast flank of Raivavae Island. If we extend the track eastward in order to find the youngest event, we find President Thiers guyot where DR21 was collected. Its isotopic signature is not far from that of the Raivavae field but only a radiometric age will settle the question.

(2) The Arago (DR7) track appears more homogeneous and could be related to the young Rurutu volcanic episode (1 Ma). Along this track, DR2 (2.6 Ma), a sample dredged on a seamount westward of Rimatara Island, has the same signature. Rimatara Island samples, although dated at $27 \mathrm{Ma}$ [8], are clearly belonging to the Young Rurutu episode. The Rimatara Island is thus likely belonging to this track and we think that the existing radiometric age already questioned by several authors is definitively an error. At the oldest end of the track, Atiu and Mauke, have less radiogenic Nd isotopes and their belonging to the track is thus more questionable, although one Mauke sample is close to the young Rurutu field. 
(3) The Macdonald track source is more heterogeneous than the other tracks, at the scale of the track as well as at the scale of each volcano. The volcano scale heterogeneity is seen especially in Nd isotopes in samples from Macdonald, Rapa, Marotiri and DR14-3, dated at 8.8 Ma. The track heterogeneity is illustrated by the difference in isotopic signature between Macdonald (0 Ma) and Mangaia whose age (19 Ma) is in agreement with the age along the track.

From the above description of mantle isotopic characteristics associated with each of these three hot spot tracks, it can be deduced that the mantle tapped in the last $20 \mathrm{Ma}$ is more radiogenic and more heterogeneous than earlier. Further detailed work on identifying the different volcanic episodes present in the different volcanoes in correlation with basement ages would be needed to raise reasonable hypotheses about the causes of such heterogeneities. We certainly can assume that the superplume mantle source was heterogeneous to start with $20 \mathrm{Ma}$ ago. And we can safely state that mixing of sources combined with crustal assimilation would increase the observed degree of heterogeneity within each hotspot track.

\section{Lithospheric control}

As described earlier, geochemical heterogeneities are present even at the scale of a single volcano. On some island or seamount, important differences in geochemical signatures can be pointed out. These signatures however clearly belong to different volcanic stages separated in time by several millions of years. This is well known on Rurutu Island [25] with two stages dated at 12 Ma (old Rurutu stage) and 1 Ma (Young Rurutu stage). Furthermore, if we consider the nearby Lotus bank with a sample dated at 54.8 Ma, we can conclude that at least three different stages have occurred in the same area. The present study also reveals that Arago Seamount experienced two volcanic stages separated by 8.7 m.y. (DR7 and DR7b samples) with distinct isotopic signatures. On the other hand, DR14 and DR23 samples are presenting different isotopic signatures but we don't know their difference in ages. We can therefore assume that each of them has sampled two separate episodes of volcanism in the same way as two volcanic stages have been identified in Rurutu island or Arago Seamount. During such a time interval (around 10 m.y.), the Pacific plate has moved $1200 \mathrm{~km}$ to the Northwest and the volcanic activity cannot correspond to the same mantle source. To explain such reoccurrence of volcanism at the same location, we have to assume that the lithosphere is weakened along the path taken by the magma to reach the surface. This weakened area then acts as the preferential pathway for subsequent magmatic events that bring magma from new plume sources to the surface.

\section{6 - Conclusion}

Based on the most complete to date oceanic sampling of the Cook-Austral volcanic chains, we have shown:

- a huge heterogeneity in mantle sources at the regional scale;

- a chemical grouping of the mantle sources during the three identified volcanic stages of 58-40 Ma, 33-20 Ma and 20-0 Ma with signatures of mantle reservoir composition from close to $\mathrm{C}$ to $\mathrm{N}$-MORB-types and C/HIMU-type respectively.

- a mantle heterogeneity along each hotspot track during the most recent volcanic period of 0-20 Ma;

- an heterogeneity at the scale of a volcano due to the occurrence of different magmatic phases at the same location;

- the importance of the structural control, either crustal or lithospheric, in the location of magma outputs.

These observations taken together are in good agreement with a model where each hot spot could sample one volume of the large and very heterogeneous plume responsible for the regional swell of the seafloor topography [1]. It has been proposed that this small scale convection (100 km in surface expression compared to the $2000 \mathrm{~km}$ of the Superswell) could be due to secondary instabilities developing at the surface of the larger plume in the transition 
zone [26]. The time constants of these phenomena should give us constraints to infer the size of the mantle heterogeneities described in this study. At the regional scale, the challenge is to decipher the dynamics of the super-plume responsible for the Superswell, given the time evolution of the mantle source composition.

\section{Acknowledgments}

The authors wish to thank Sophie Bernard, Marcel Bohn, Claire Bollinger, Henri Bougault, Joël Etoubleau, Philip Janney and Raymond Le Suavé for their help with data acquisition, analytical work and discussions. This paper has been greatly improved thanks to the detailed comments of reviewers P. Castillo and G. Ito.

The ZEPOLYF2 cruise was funded by the government of French Polynesia in the framework of the ZEPOLYF program. Analytical work was financed by INSU-CNRS and IFREMER. This is IPGP contribution number 2077 and IUEM contribution number 980. 


\section{Figure captions}

Figure 1: Location of the Cook-Austral Islands in the southwest Pacific with indication of the main structural features and names of main sampled islands. The box corresponds to the studied area displayed in Figure 2.

Figure 2: Ages of seafloor and island volcanoes reported on a shaded view of seafloor topography for the Cook-Austral region. The $34 \mathrm{j}$ anomaly (84 Ma) marks the beginning of the Cretaceous quiet zone and west of this anomaly ( 1ongitude $\left.152^{\circ} \mathrm{W}\right)$, the crust has an age comprised between 84 and 118 Ma. White lines represent crustal magnetic anomalies, and their corresponding age is in white numbers (Ma). Black diamonds represent places where $\mathrm{K}$ $\mathrm{Ar}$ or $\mathrm{Ar} / \mathrm{Ar}$ ages (Ma, in black italic) are known. Dredge location and sample numbers are in red.

Figure 3: (a) and (b) DR07 pillow lava observed in thin section. (c) nepheline phenocrysts can be observed within the vesicular altered groundmass.

Figure 4: Extraction of the microlitic plagioclase from DR24-02 basalt, using the double separation technique: (a) crushing at an appropriate size to remove unsuitable phenocrysts; (b) re-crushing and sieving at a smaller size to extract the plagioclase microlites (c).

Figure 5: $\mathrm{SiO}_{2}$ vs. $\mathrm{Na}_{2} \mathrm{O}+\mathrm{K}_{2} \mathrm{O}$ for Table 2 data. The field boundaries are from [27] and [28] for the dashed line. DR14-4 is a basaltic breccia rich in clinopyroxenes shown by a slashed circle.

Figure 6: Primitive-mantle normalized extended rare earth patterns for analyzed samples shown in Table 2. The elements are in decreasing incompatibility order for mantle derived melts. Open symbols are used for non-rare earth elements, Th, Ta, $\mathrm{Nb}$ and $\mathrm{Zr}$, Hf [18]. The samples are organized in age groups according to absolute dating or estimated age when italic fonts are used. Grey areas include samples that have similar patterns.

Figure 7: Nd vs. Sr isotopic diagram for published data from the Austral islands [3, 20, 2934] and Marquesas [35-40], Society [33, 40] and Pitcairn [41-44] islands as well as Pacific mid-ocean ridge basalts [45-47, 48 , 49-65] and main mantle reservoirs HIMU, EMI and EMII. The numbers in the inset refer to ZEPOLYF2 and POLYDRAG samples. Analytical errors are smaller than symbol sizes. All samples are represented by circles, black for old (40$58 \mathrm{Ma})$, grey for middle age (20-33 Ma) and white for young (0-20 Ma). DR14-4 dominated by clinopyroxene has a slashed circle as a symbol.

Figure 8: $\mathrm{Pb}-\mathrm{Pb}$ diagrams with available data from the literature as specified in Figure 7 caption and additional references [66-70] for Pacific mid-ocean ridge basalts. NHRL stands for Northern Hemisphere Line [71]. The numbers in the insets refer to ZEPOLYF2 and POLYDRAG samples. Analytical errors are smaller than symbol sizes. Symbols are defined in Figure 7.

Figure 9: (a) ${ }^{208} \mathrm{~Pb} /{ }^{206} \mathrm{~Pb}$ vs. ${ }^{207} \mathrm{~Pb} /{ }^{206} \mathrm{~Pb}$ diagram with available data from the literature as specified in Figures 7 and 8. (b) ${ }^{206} \mathrm{~Pb} /{ }^{204} \mathrm{~Pb}$ and c) $\Delta^{207} \mathrm{~Pb} /{ }^{204} \mathrm{~Pb}$ (deviation from NHRL [71]) versus Th/Ta for studied samples. Symbols are defined in Figure 7.

Figure 10: ${ }^{143} \mathrm{Nd} /{ }^{144} \mathrm{Nd}$ vs. ${ }^{206} \mathrm{~Pb} /{ }^{204} \mathrm{~Pb}$ diagram with available data from the literature as specified in Figures 7 and 8 captions. Green, blue and red symbols are used for samples belonging to hotspot tracks shown in Figure 11. Black circles are used for samples dated between 40 and 58 Ma. Yellow squares are used for 33 to 20 Ma samples. The stippled area indicates samples from 0-20 Ma. 
Figure 11: Bathymetric map with hotspot-track reconstruction for the three groups of volcanoes (see text). Map projection is made along direction of present motion of Pacific plate (from right to left). White italic numbers indicate time in Ma along each track. Note that northernmost track starts at 6.5 Ma for last volcanic event known on this track. A black star represents active Macdonald seamount. The new K-Ar ages obtained in the present study are in black and their exact location are given by the symbols defined in Figure 10. The known ages of islands are given in Figure 2. 


\section{References}

[1] M.K. McNutt and K.M. Fischer, The south Pacific Superswell, in: Seamounts, Islands and Atolls, B. Keating, P. Fryer, R. Batiza and G. Boethlert, eds., Geophys. Monogr. 43, pp. 25-34, AGU, Washington D.C., 1987.

[2] H. Staudigel, K.-H. Park, M. Pringle, J.L. Rubenstone, W.H.F. Smith and A. Zindler, The longevity of the South Pacific isotopic and thermal anomaly, Earth and Planetary Science Letters 102, 24-44, 1991.

[3] P. Schiano, K.W. Burton, B. Dupre, J.L. Birck, G. Guille and C.J. Allegre, Correlated Os$\mathrm{Pb}-\mathrm{Nd}-\mathrm{Sr}$ isotopes in the Austral-Cook chain basalts: the nature of mantle components in plume sources, Earth and Planetary Science Letters 186(3-4), 527-537, 2001.

[4] V. Clouard, A. Bonneville and P.Y. Gillot, The Tarava seamounts: a new but exinct hotspot chain on the South Pacific Superswell, Earth Plan. Sc. Letts 207, 117-130, 2003.

[5] C.L. Mayes, L.A. Lawver and D.T. Sandwell, Tectonic history and new isochron chart of the South Pacific, Journal of Geophysical Research 95(B6), 8543-8567, 1990.

[6] M.K. McNutt, D.W. Caress, J. Reynolds, K.A. Jordahl and R.A. Duncan, Failure of plume theory to explain midplate volcanism in the Southern Austral islands, Nature 389, 479-482, 1997.

[7] N. Baudry, U. Von Stackelberg and J. Récy, Alignements volcaniques dans les iles Australes: Analyse et interprétation des données SEASAT et Seabeam, C. R. Acad. Sci. - Paris 306(Série II), 643-648, 1988.

[8] D.L. Turner and R.D. Jarrard, K/Ar dating of the Cook Austral island chain; a test of the hot spot hypothesis., Journal of Volcanology and Geothermal Research 12, 187-220, 1982.

[9] H. Barsczus, G. Guille, R.C. Maury, C. Chauvel and H. Guillou, Two magmatic sources at Rurutu Island (Austral Islands, French Polynesia) and the Austral "hotline", Eos, Transactions, American Geophysical Union. 75; 16, Suppl., Pages 323. 1994., 1994.

[10] A. Bonneville, R. Le Suavé, L. Audin, V. Clouard, L. Dosso, P.-Y. Gillot, P. Janney, A. Jordahl Kelsey and K. Maamaatuaiahutapu, Arago Seamount : The missing hot spot found in the Austral Islands, Geology 30(11), 1023-1026, 2002.

[11] G.B. Dalrymple and M.A. Lanphere, Potassium-Argon Dating. Principles, techniques and applications to geochronology, 258 pp., W.H. Freeman and Co., San Francisco, 1969.

[12] P.Y. Gillot and Y. Cornette, The Cassignol technique for potassium-argon dating, precision and accuracy: examples from late Pleistocene to recent volcanics from southern Italy, Chemical Geology 59, 205-222, 1986.

[13] I. McDougall and T.M. Harrison, Geochronology and Thermochronology by the 40Ar/39Ar Method, 269 pp., Oxford University Press, New York, 1999.

[14] C. Cassignol and P.Y. Gillot, Range and effectiveness of unspiked potassium-argon dating: Experimental groundwork and applications, J. Wiley, ed., pp. 159-179, New York, 1982.

[15] L. Dosso, H. Bougault and J.L. Joron, Geochemical morphology of the North MidAtlantic Ridge, $10^{\circ}-24^{\circ} \mathrm{N}$ : Trace element-isotopes complementarity, Earth and Planetary Science Letters 120, 443-462, 1993.

[16] M. Regelous, A.W. Hofmann, W. Abouchami and S.J.G. Galer, Geochemistry of lavas from the Emperor Seamounts, and the geochemical evolution of Hawaiian magmatism from 85 to 42 Ma, Journal of Petrology 44(1), 113-140, 2003.

[17] O. Ishizuka, R.N. Taylor, J.A. Milton and R.W. Nesbitt, Fluid-mantle interaction in an intra-oceanic arc: constraints from high-precision $\mathrm{Pb}$ isotopes, Earth and Planetary Science Letters 211, 221-236, 2003. 
[18] S.S. Sun and W.F. McDonough, Chemical and isotopic systematics of oceanic basalts: implications for mantle composition and processes, in: Magmatism of the Ocean Basins, A.D. Saunders and M.J. Norry, eds. 42, pp. 313-345, Geol. Soc. Spec. Publication, 1989.

[19] P. Bienvenu, H. Bougault, J.L. Joron, M. Treuil and L. Dmitriev, MORB alteration : rare-earth element/non rare-earth hygromagmaphile element fractionation, Chemical Geology 82, 1-14, 1990.

[20] C. Chauvel, W. McDonough, G. Guille, R. Maury and R. Duncan, Contrasting old and young volcanism in Rurutu Island, Austral chain, Chemical Geology 139(1-4), 125-143, 1997.

[21] B.B. Hanan and D.W. Graham, Lead and Helium Isotope Evidence from Oceanic Basalts for a Common Deep Source of Mantle Plumes, Science 272, 991-995, 1996.

[22] S.R. Hart, E.H. Hauri, L.A. Oschmann and J.A. Whitehead, Mantle plumes and entrainment: isotopic evidence, Science 256, 517-520, 1992.

[23] P. Wessel and L. Kroenke, A geometric technique for relocating hotspots and refining absolute plate motions, Nature 387, 365-369, 1997.

[24] C.Y. Yan and L.W. Kroenke, A plate tectonic reconstruction of the Southwest Pacific, 0-100 Ma, in: Proceeedings of the Ocean Drilling Project, Scientific Results 130, pp. 697-709, 1993.

[25] R.A. Duncan and W. Compston, Sr isotopic evidence for an old mantle source region for French Polynesian volcanism, Geology 4, 728-732, 1976.

[26] A. Davaille, Simultaneous generation of hotspots and superswells by convection in a heterogeneous planetary mantle, Nature 402, 756-760, 1999.

[27] R.W. Le Maitre, P. Bateman, A. Dudek, J. Keller, M.J.L.L. Bas, P.A. Sabine, R. Schmid, H. Sorensen, A. Streckeisen, A.R. Woolley and B. Zanettin, A classification of igneous rocks and glossary of terms, 193 pp., Oxford, 1989.

[28] G.A. MacDonald and T. Katsura, Chemical composition of hawaiian lavas, Journal of Petrology 5, 83-133, 1964.

[29] Y. Nakamura and M. Tatsumoto, Pb, Nd, and Sr isotopic evidence for a multicomponent source for rocks of Cook-Austral Islands and heterogeneities of mantle plumes, Geochimica et Cosmochimica Acta 52(12), 2909-2924, 1988.

[30] Z.A. Palacz and A.D. Saunders, Coupled trace element and isotope enrichment in the Cook-Austral-Samoa islands, southwest Pacific, Earth and Planetary Science Letters 79, 270-280, 1986.

[31] E.H. Hauri and S.R. Hart, Re Os isotope systematics of HIMU and EMII oceanic island basalts from the South Pacific Ocean., Earth and Planetary Science Letters 114, 353371, 1993.

[32] T. Kogiso, Y. Tatsumi, G. Shimoda and h.G. Barsczus, High $\mu$ (HIMU) ocean Island Basalts in Southern Polynesia: New Evidence for Whole Mantle Scale Recycling of Subducted Oceanic Crust, Journal of Geophysical Research 102(B4), 8085-8103, 1997.

[33] C. Hemond, C.W. Devey and C. Chauvel, Source compositions and melting processes in the Society and Austral plumes (South Pacific Ocean); element and isotope (Sr, Nd, Pb, Th) geochemistry., Chemical Geology 115, 7-45, 1994.

[34] J.D. Woodhead, Extreme HIMU in an oceanic setting; the geochemistry of Mangaia Island (Polynesia), and temporal evolution of the Cook-Austral hotspot, Journal of Volcanology and Geothermal Research 12(3-4), 187-220, 1996.

[35] D.L. Desonie, R.A. Duncan and J.H. Natland, Temporal and geochemical variability of volcanic products of the Marquesas hotspot, Journal of Geophysical Research 98, 17,649-17,665, 1993.

[36] J.M. Liotard, H.G. Barsczus, C. Dupuy and J. Dostal, Geochemistry and origin of basaltic lavas from Marquesas Archipelago, French Polynesia, Contributions to Mineralogy and Petrology 92, 260-268, 1986. 
[37] R.A. Duncan, M.T. Mc Culloch, H.G. Barsczus and D.R. Nelson, Plume versus lithospheric sources for melts at Ua Pou, Marquesas Islands, Nature 322, 534-538, 1986.

[38] P. Vidal, C. Chauvel and R. Brousse, Large mantle heterogeneity beneath French Polynesia., Nature (London) 307, 536-538 42 Refs., 1984.

[39] J.D. Woodhead, Temporal geochemical evolution in oceanic intra-plate volcanics; a case study from the Marquesas (French Polynesia) and comparison with other hotspots, Contributions to Mineralogy and Petrology 111, 458-467, 1992.

[40] Q.C. Cheng, J.D. Macdougall and G.W. Lugmair, Geochemical studies of Tahiti, Teahitia and Mehetia, Society Island Chain., J. Volcanol. Geotherm. Res. 55, 155-184, 1993.

[41] J.D. Woodhead and C.W. Devey, Geochemistry of the Pitcairn Seamounts .1. Source Character and Temporal Trends, Earth and Planetary Science Letters 116, 81-99, 1993.

[42] J.D. Woodhead and M.T. McCulloch, Ancient seafloor signals in Pitcairn Island lavas and evidence for large amplitude, small length-scale mantle heterogeneities, Earth and Planetary Science Letters 94, 257-273, 1989.

[43] C. Dupuy, P. Vidal, R.C. Maury and G. Guille, Basalts from Mururoa, Fangataufa and Gambier islands (French Polynesia); geochemical dependence on the age of the lithosphere, Earth and Planetary Science Letters 117, 89-100, 1993.

[44] J. Eisele, M. Sharma, S.J.G. Galer, J. BlichertToft, C.W. Devey and A.W. Hofmann, The role of sediment recycling in EM-1 inferred from $\mathrm{Os,} \mathrm{Pb}, \mathrm{Hf}, \mathrm{Nd}, \mathrm{Sr}$ isotope and trace element systematics of the Pitcairn hotspot, Earth and Planetary Science Letters 196, 197-212, 2002.

[45] W.M. White, A.W. Hofmann and H. Puchelt, Isotope geochemistry of Pacific MidOcean Ridge Basalt, Journal of Geophysical Research 92(B6), 4881-4893, 1987.

[46] J.J. Mahoney, J.M. Sinton, M.D. Kurz, J.D. Macdougall, K.J. Spencer and G.W. Lugmair, Isotope and trace element characteristics of a super-fast spreading ridge: East Pacific rise, 13-23으, Earth and Planetary Science Letters 121, 173-193, 1994.

[47] Y.L. Niu, D.G. Waggoner, J.M. Sinton and J.J. Mahoney, Mantle source heterogeneity and melting processes beneath seafloor spreading centers: The East Pacific Rise, 18 degrees-19S, Journal of Geophysical Research 101(B12), 27711-27733, 1996.

[48] W. Bach, E. Hegner, J. Erzinger and M. Satir, Chemical and Isotopic Variations Along the Superfast Spreading East Pacific Rise from 6 degrees S to 30 degrees S, Contribution to Mineralogy and Petrology 116(4), 365-380, 1994.

[49] J.D. Macdougall and G.W. Lugmair, Sr and Nd isotopes in basalts from the East Pacific Rise: significance for mantle heterogeneity, Earth and Planetary Science Letters 77, 273-284, 1986.

[50] E. Ito, W.M. White and C. Göpel, The O, Sr, $\mathrm{Nd}$ and $\mathrm{Pb}$ isotope geochemistry of MORB, Chemical Geology 62, 157-176, 1987.

[51] W.M. White and A.W. Hofmann, Sr and Nd isotope geochemistry of oceanic basalts and mantle evolution, Nature 296, 821-825, 1982.

[52] R.S. Cohen, N.M. Evensen, P.J. Hamilton and R.K. O'Nions, U-Pb, Sm-Nd and Rb-Sr systematics of mid-ocean ridge basalt glasses, Nature 283, 149-153, 1980.

[53] R.S. Cohen and R.K. O'Nions, The lead, neodymium and strontium isotopic structure of ocean ridge basalts, Journal of Petrology 23, 299-324, 1982.

[54] E. Hegner and M. Tatsumoto, Pb, Sr, and Nd isotopes in basalts and sulfides from the Juan de Fuca Ridge, Journal of Geophys. Res. 92, 11380-11386, 1987.

[55] A. Prinzhofer, E. Lewin and C.J. Allègre, Stochastic melting of the marble cake mantle: evidence from local study of the East Pacific Rise at $12^{\circ} 50^{\prime} \mathrm{N}$, Earth and Planetary Science Letters 92, 189-206, 1989. 
[56] P. Schiano, J.L. Birck and C.J. Allegre, Osmium-strontium-neodymium-lead isotopic covariations in mid-ocean ridge basalt glasses and the heterogeneity of the upper mantle, Earth and Planetary Science Letters 150(3-4), 363-379, 1997.

[57] S.P. Verma, J.G. Schilling and D.G. Waggoner, Neodynium isotopic evidence for Galapagos hotspot-spreading centre system evolution, Nature 306, 654-657, 1983.

[58] W. Bach, J. Erzinger, L. Dosso, C. Bollinger, H. Bougault, J. Etoubleau and J. Sauerwein, Unusually large Nb-Ta depletions in North Chile ridge basalts at 36 degrees 50' to 38 degrees 56'S: Major element, trace element, and isotopic data, Earth and Planetary Science Letters 142(1-2), 223-240, 1996.

[59] E.M. Klein and J.L. Karsten, Ocean-ridge basalts with convergent-margin geochemical affinities from the Chile Ridge, Nature 374(6517), 52-57, 1995.

[60] J.D. Macdougall and G.W. Lugmair, Extreme isotopic homogeneity among basalts from the southern East Pacific Rise: mantle or mixing effect?, Nature 313, 209-211, 1985.

[61] P.R. Castillo, J. Natland, Y. Niu and P.F. Lonsdale, Sr, Nd and Pb isotopic variation along the Pacific -antarctic risecrest, $53-57^{\circ} \mathrm{S}$ : implications for the composition and dynamics of the South Pacific upper mantle, Earth and Planetary Science Letters 154, 109-125, 1998.

[62] E.M. Ferguson and E.M. Klein, Fresh Basalts from the Pacific Antarctic Ridge Extend the Pacific Geochemical Province, Nature 366(6453), 330-333, 1993.

[63] D.G. Pyle, D.M. Christie and J.J. Mahoney, Resolving an Isotopic Boundary Within the Australian-Antarctic Discordance, Earth Planet Sci Lett 112(1-4), 161-178, 1992.

[64] E.M. Klein, C.H. Langmuir, A. Zindler, H. Staudigel and B. Hamelin, Isotope evidence of a mantle convection boundary at the Australian-Antartic discordance, Nature 333, 623-629, 1988.

[65] I. Vlastelic, L. Dosso, H. Bougault, D. Aslanian, L. Geli, J. Etoubleau, M. Bohn, J.L. Joron and C. Bollinger, Chemical systematics of an intermediate spreading ridge: The Pacific-Antarctic Ridge between 56 degrees S and 66 degrees S, J Geophys Res Solid Earth 105(B2), 2915-2936, 2000.

[66] B. Dupré, B. Lambret, D. Rousseau and C.J. Allègre, Limitations on the scale of mantle heterogeneities under oceanic ridges, Nature 294, 552-554, 1981.

[67] S.E. Church and M. Tatsumoto, Lead isotope relations in oceanic ridge basalts from the Juan de Fuca-Gorda Ridge area, N.E. Pacific Ocean, Contrib. Mineral. Petrol. 53, 253279, 1975.

[68] S.S. Sun, Lead isotopic study of young volcanic rocks from mid-ocean ridges, ocean islands and island arcs, Phil. Trans. R. Soc. Lond. A 297, 409-445, 1980.

[69] D. Fontignie and J.-G. Schilling, ${ }^{87} \mathrm{Sr} /{ }^{86} \mathrm{Sr}$ and REE variations along the Easter Microplate boundaries (south Pacific): Application of multivariate statistical analyses to ridge segmentation, Chemical Geology 89, 209-241, 1991.

[70] B.B. Hanan and J.-G. Schilling, Easter microplate evolution: Pb isotope evidence, Journal of Geophysical Research 94, 7432-7448, 1989.

[71] S.R. Hart, A large scale isotope anomaly in the Southern Hemisphere mantle, Nature 309, 753-757, 1984. 
Tables

Table 1 : Results of the K-Ar dating

\begin{tabular}{|c|c|c|c|c|c|c|c|}
\hline Sample & Phase & $\begin{array}{l}\text { range of crystal } \\
\text { sizes (microns) }\end{array}$ & $\mathrm{K} \%$ & $40 \mathrm{Ar}^{\star}(\%)$ & $40 A r^{*}(\mathrm{at} / \mathrm{g})$ & Age (Ma) & Uncertainty \\
\hline DR01 & plagioclase & $125-250$ & 0.199 & $71.13 \%$ & $1.2357 \mathrm{E}+13$ & 58.5 & 0.8 \\
\hline \multirow[t]{2}{*}{ DR01 } & plagioclase & $125-250$ & 0.199 & $72.56 \%$ & $1.2171 E+13$ & 57.6 & 0.8 \\
\hline & & & & & mean & 58.1 & 0.8 \\
\hline DR02 & groundmass & $125-250$ & 0.826 & $6.86 \%$ & $2.2481 E+12$ & 2.57 & 0.05 \\
\hline \multirow[t]{2}{*}{ DR02 } & groundmass & $125-250$ & 0.826 & $6.23 \%$ & $2.3029 E+12$ & 2.63 & 0.06 \\
\hline & & & & & mean & 2.60 & 0.05 \\
\hline DR04 & groundmass & $125-250$ & 0.909 & $70.48 \%$ & $1.1813 E+13$ & 12.2 & 0.2 \\
\hline \multirow[t]{2}{*}{ DR04 } & groundmass & $125-250$ & 0.909 & $65.96 \%$ & $1.1865 E+13$ & 12.3 & 0.2 \\
\hline & & & & & & 12.2 & 0.2 \\
\hline DR05 & plagioclase & $80-125$ & 0.333 & $69.34 \%$ & $1.9481 E+13$ & 55.2 & 0.8 \\
\hline \multirow[t]{2}{*}{ DR05 } & plagioclase & $80-125$ & 0.333 & $70.58 \%$ & $1.9256 \mathrm{E}+13$ & 54.5 & 0.8 \\
\hline & & & & & mean & 54.8 & 0.8 \\
\hline DR07 & nepheline & $125-250$ & 2.818 & $12.68 \%$ & $6.7574 \mathrm{E}+11$ & 0.230 & 0.004 \\
\hline DR07 & groundmass & $125-250$ & 1.558 & $1.27 \%$ & $2.0809 E+10$ & 0.013 & 0.002 \\
\hline DRO7B & plagioclase & $50-80$ & 0.623 & $28.27 \%$ & $5.8006 \mathrm{E}+12$ & 8.89 & 0.13 \\
\hline \multirow[t]{2}{*}{ DR07Bfd } & plagioclase & $125-250$ & 0.251 & $34.96 \%$ & $2.0267 E+12$ & 7.71 & 0.11 \\
\hline & & & & & mean & 8.24 & 0.65 \\
\hline DR14-03 & groundmass & $125-250$ & 1.128 & $61.91 \%$ & $1.0340 \mathrm{E}+13$ & 8.76 & 0.13 \\
\hline \multirow[t]{2}{*}{ DR14-03 } & groundmass & $125-250$ & 1.128 & $47.11 \%$ & $1.0398 E+13$ & 8.80 & 0.13 \\
\hline & & & & & mean & 8.78 & 0.13 \\
\hline DR16-01 & plagioclase & $125-250$ & 0.377 & $56.00 \%$ & $1.5735 \mathrm{E}+13$ & 39.5 & 0.6 \\
\hline \multirow[t]{2}{*}{ DR16-01 } & plagioclase & $125-250$ & 0.377 & $55.48 \%$ & $1.5735 E+13$ & 39.5 & 0.6 \\
\hline & & & & & mean & 39.5 & 0.6 \\
\hline DR18-02 & plagioclase & $125-250$ & 0.224 & $50.25 \%$ & $6.6699 E+12$ & 28.3 & 0.4 \\
\hline \multirow[t]{2}{*}{ DR18-02 } & plagioclase & $125-250$ & 0.224 & $42.78 \%$ & $6.5168 \mathrm{E}+12$ & 27.6 & 0.4 \\
\hline & & & & & mean & 28.0 & 0.4 \\
\hline DR23-02 & plagioclase & $125-250$ & 0.146 & $47.17 \%$ & $5.1964 \mathrm{E}+12$ & 33.3 & 0.5 \\
\hline \multirow[t]{2}{*}{ DR23-02 } & plagioclase & $50-80$ & 0.271 & $30.66 \%$ & $9.2456 \mathrm{E}+12$ & 31.9 & 0.5 \\
\hline & & & & & mean & 32.7 & 0.5 \\
\hline DR24-02 & plagioclase & $40-80$ & 1.215 & $7.28 \%$ & 1.3293E+13 & 10.4 & 0.3 \\
\hline \multirow[t]{2}{*}{ DR24-02 } & plagioclase & $40-80$ & 1.215 & $17.10 \%$ & 1.3367E+13 & 10.5 & 0.2 \\
\hline & & & & & mean & 10.5 & 0.2 \\
\hline
\end{tabular}

Table 2: Major, trace element and isotopic composition of analyzed samples. Major and trace element composition analyzed by XRF (Brest), ICP-MS (C.R.P.G. Nancy) and microprobe (Brest) when in italic. All Sr isotopic measurements are obtained with $2 \sigma_{M}$ errors of less than 20 and $\mathrm{Nd}$ measurements are obtained with $2 \sigma_{\mathrm{M}}$ errors of less than 15 . Pb isotope measurements are done by double spike technique (see text). Normalization values used to present the data in the extended rare earth patterns of Figure 6 are given in parenthesis after the element name. Ages are $\mathrm{K}$-Ar dates from Table 1 or estimated when shown in italic. 


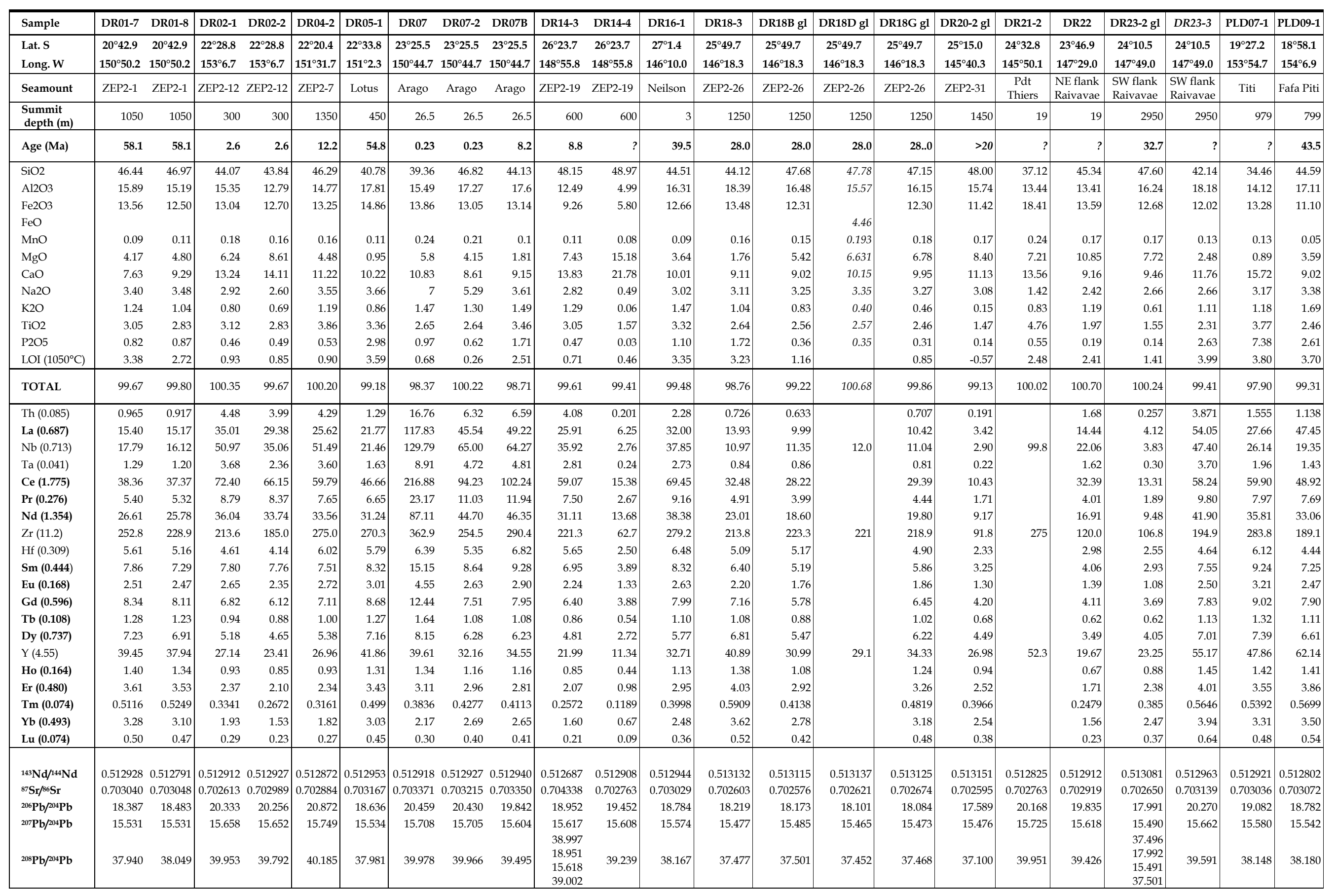




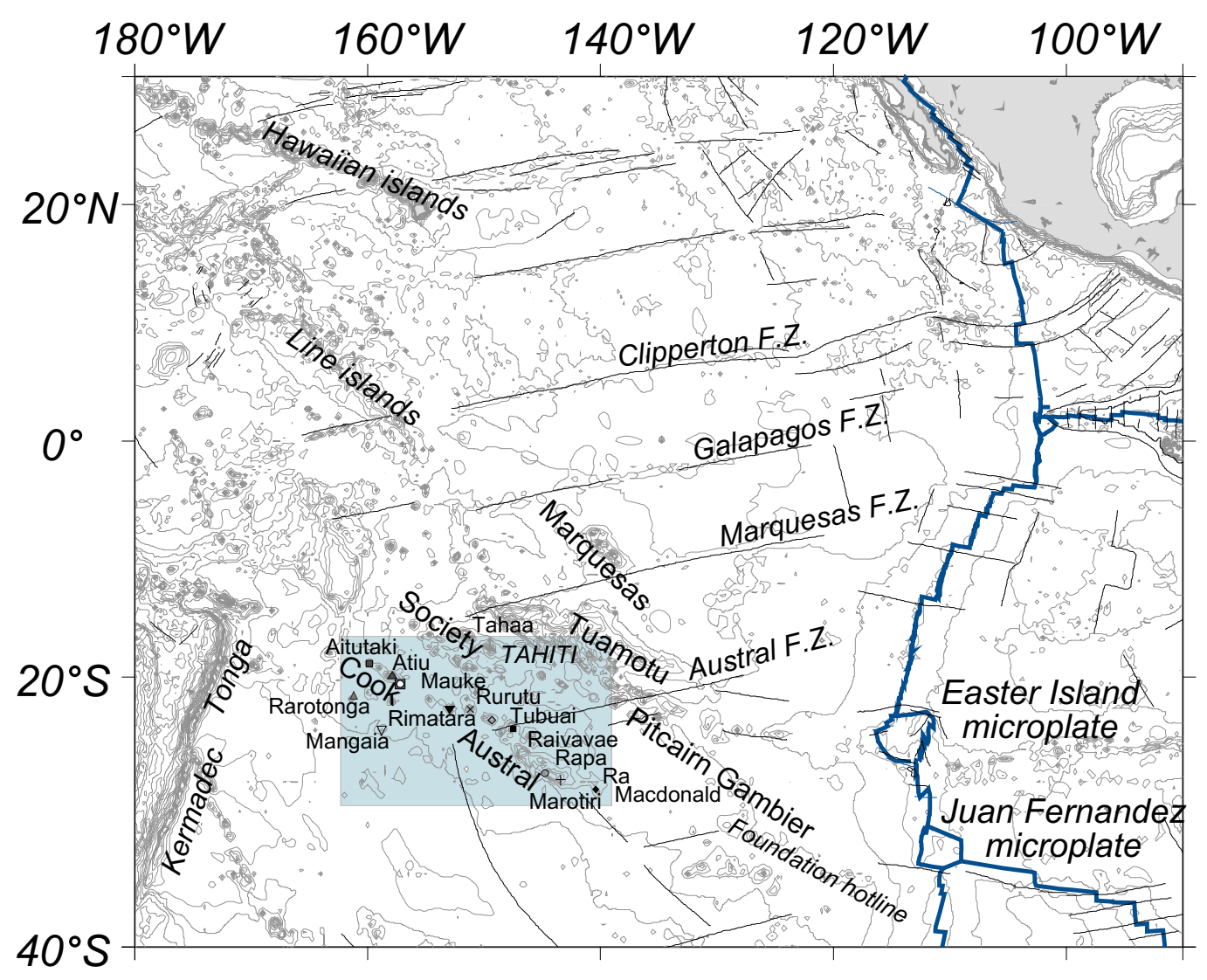

Figure 1

Bonneville et al., 2005 

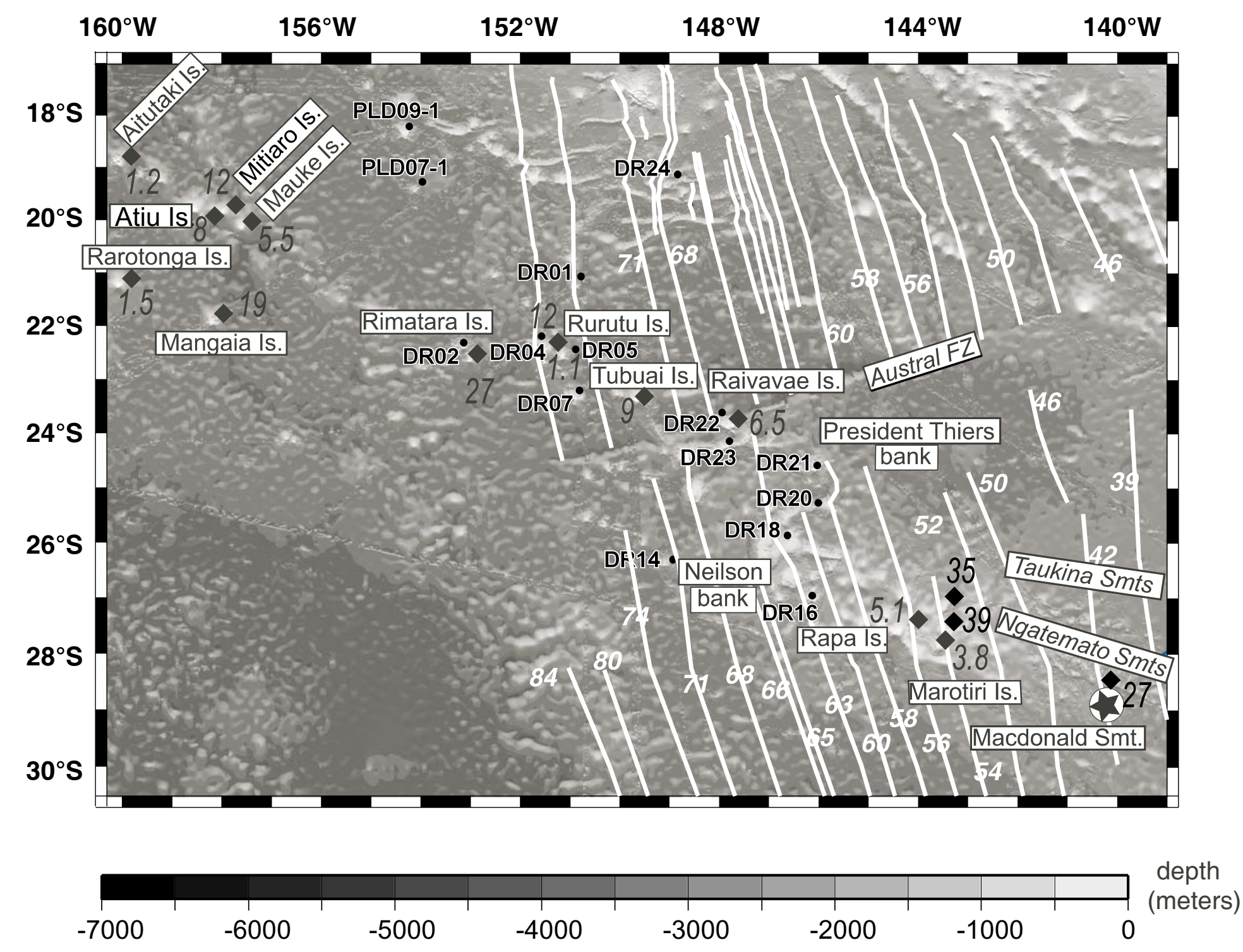

Figure 2

Bonneville et al., 2005 
(a)

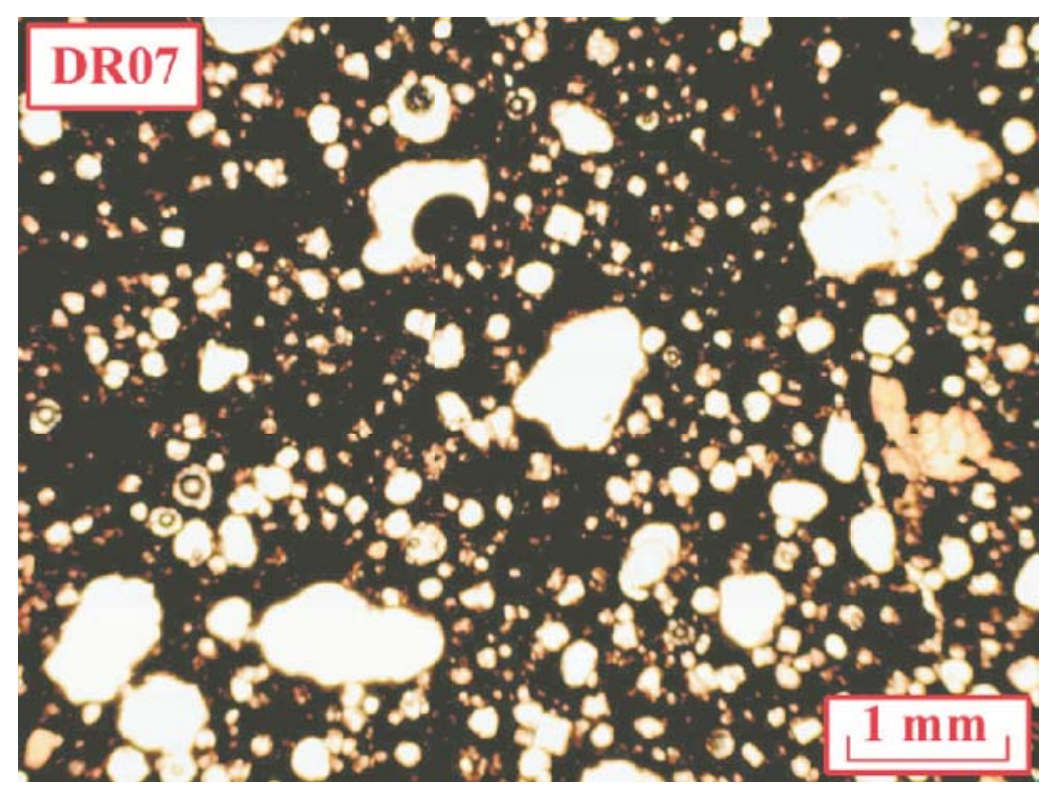

(b)

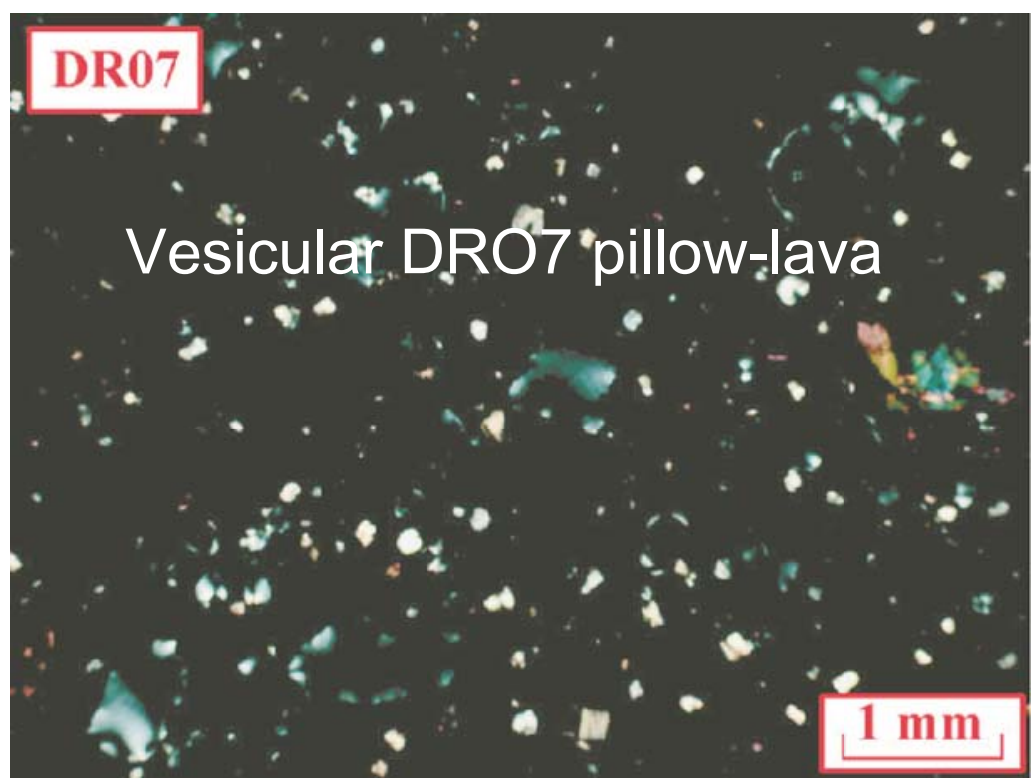

(c)

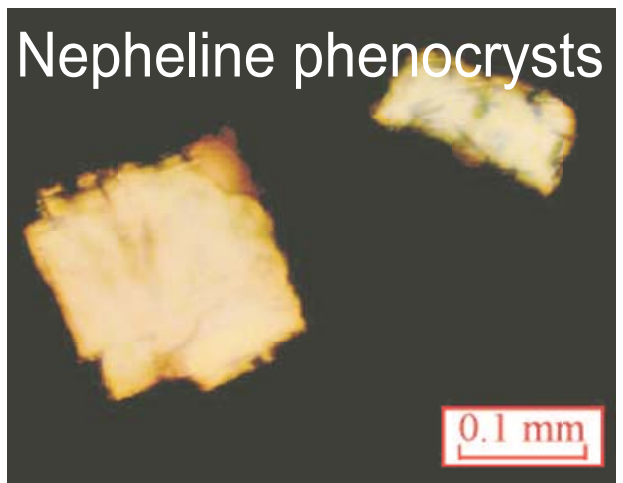

Figure 3

Bonneville et al., 2005 
Crushing and sieving at $200 \mu \mathrm{m}-400 \mu \mathrm{m}$

(a)

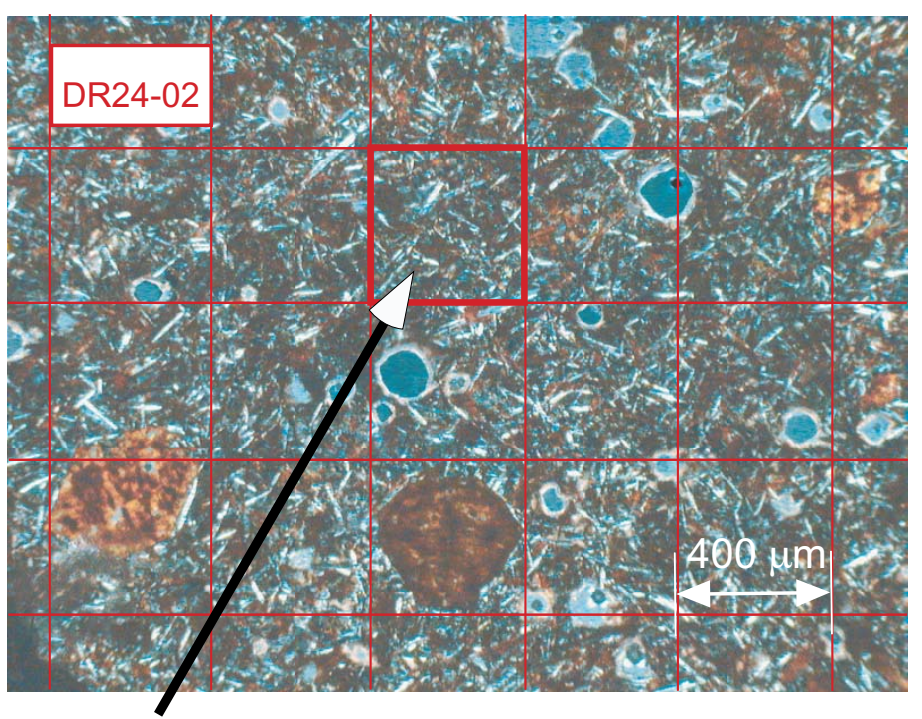

Separation of the microlitic groundmass

(b)

Crushing and sieving at $40 \mu \mathrm{m}-80 \mu \mathrm{m}$

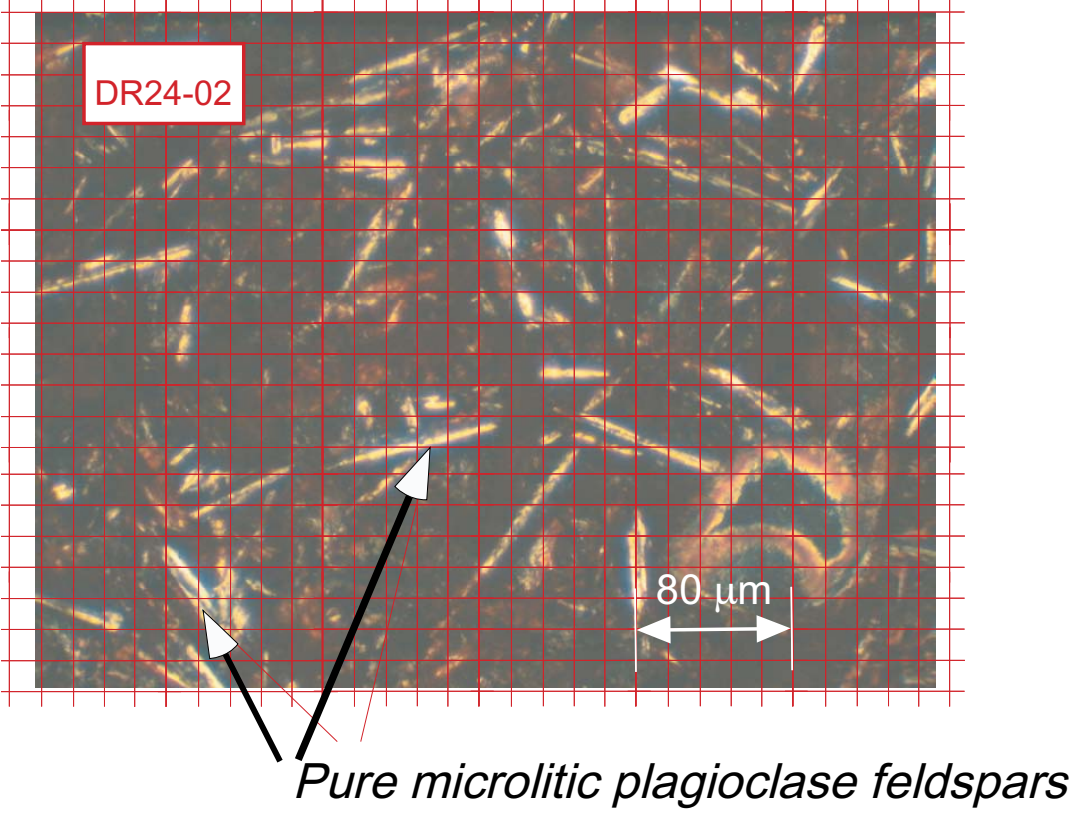

(c)

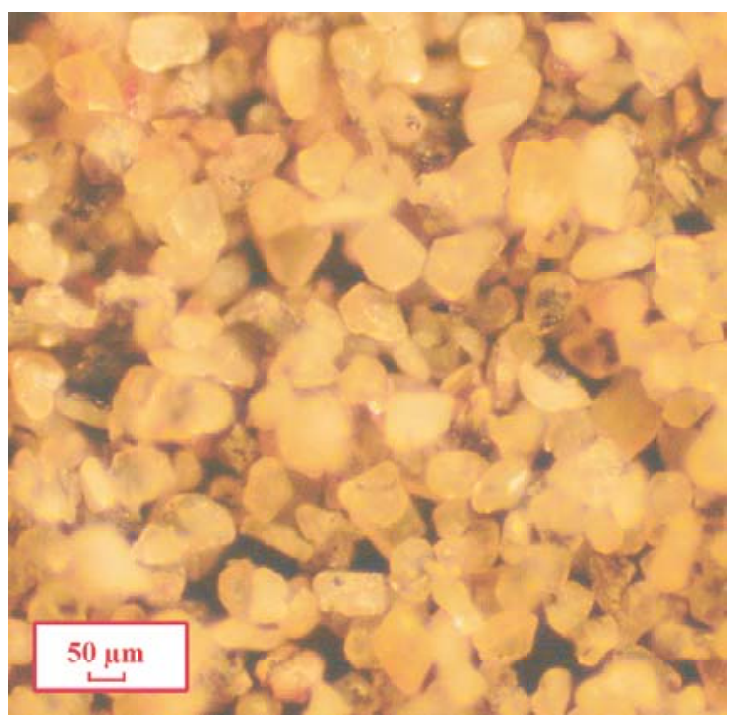

Figure 4

Bonneville et al., 2005 


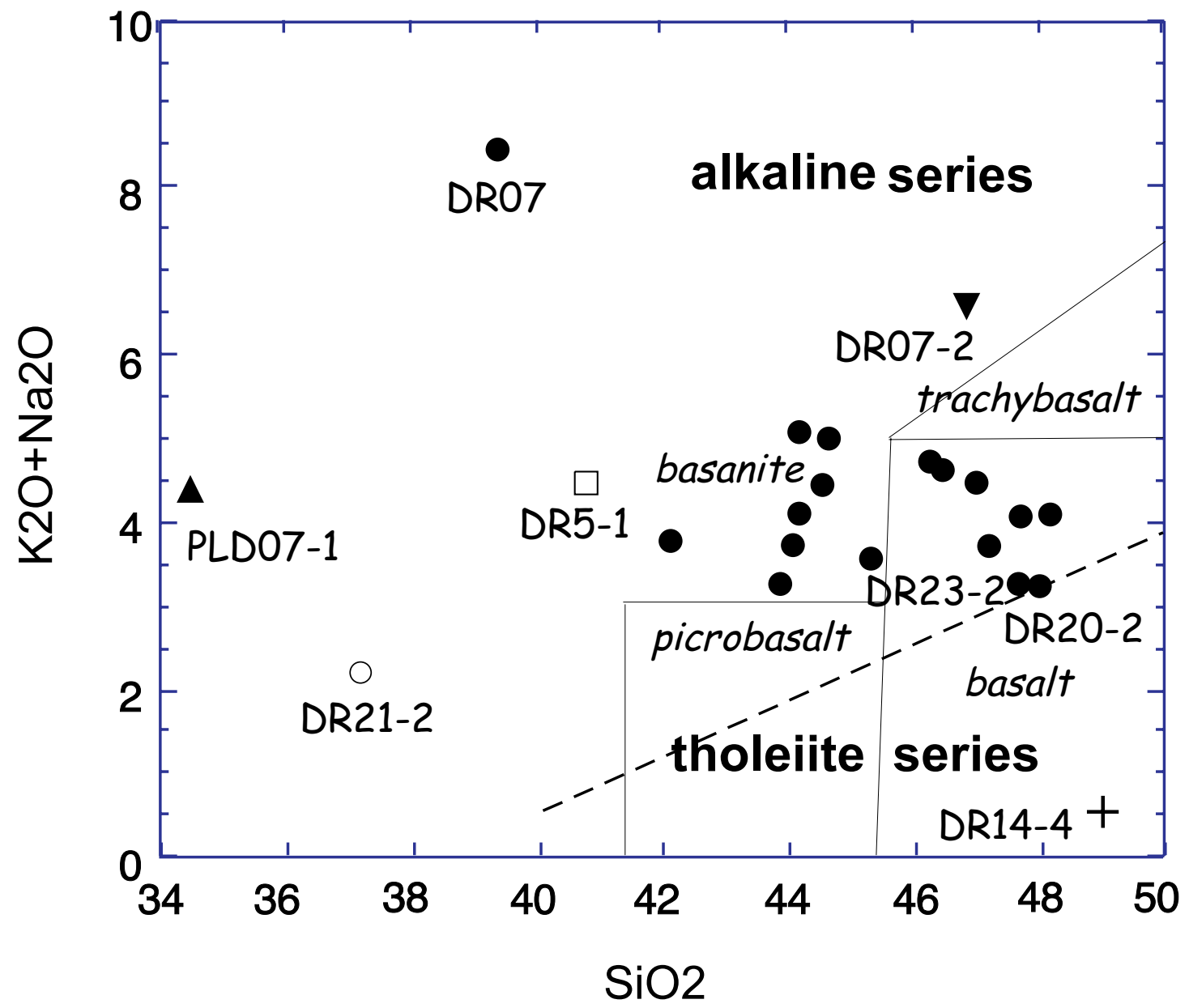

Figure 5

Bonneville et al., 2005 


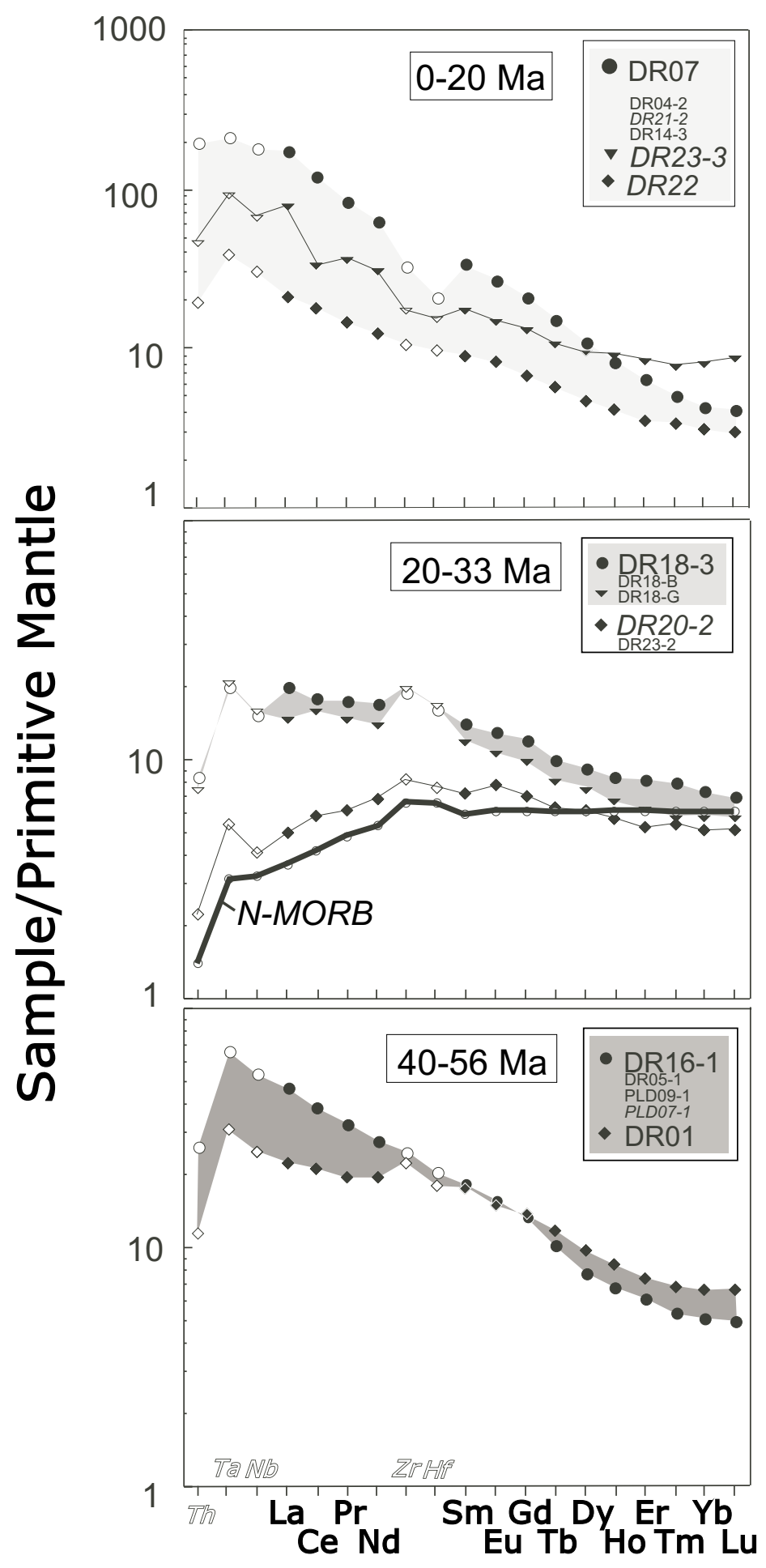

Figure 6 Bonneville et al., 2005 


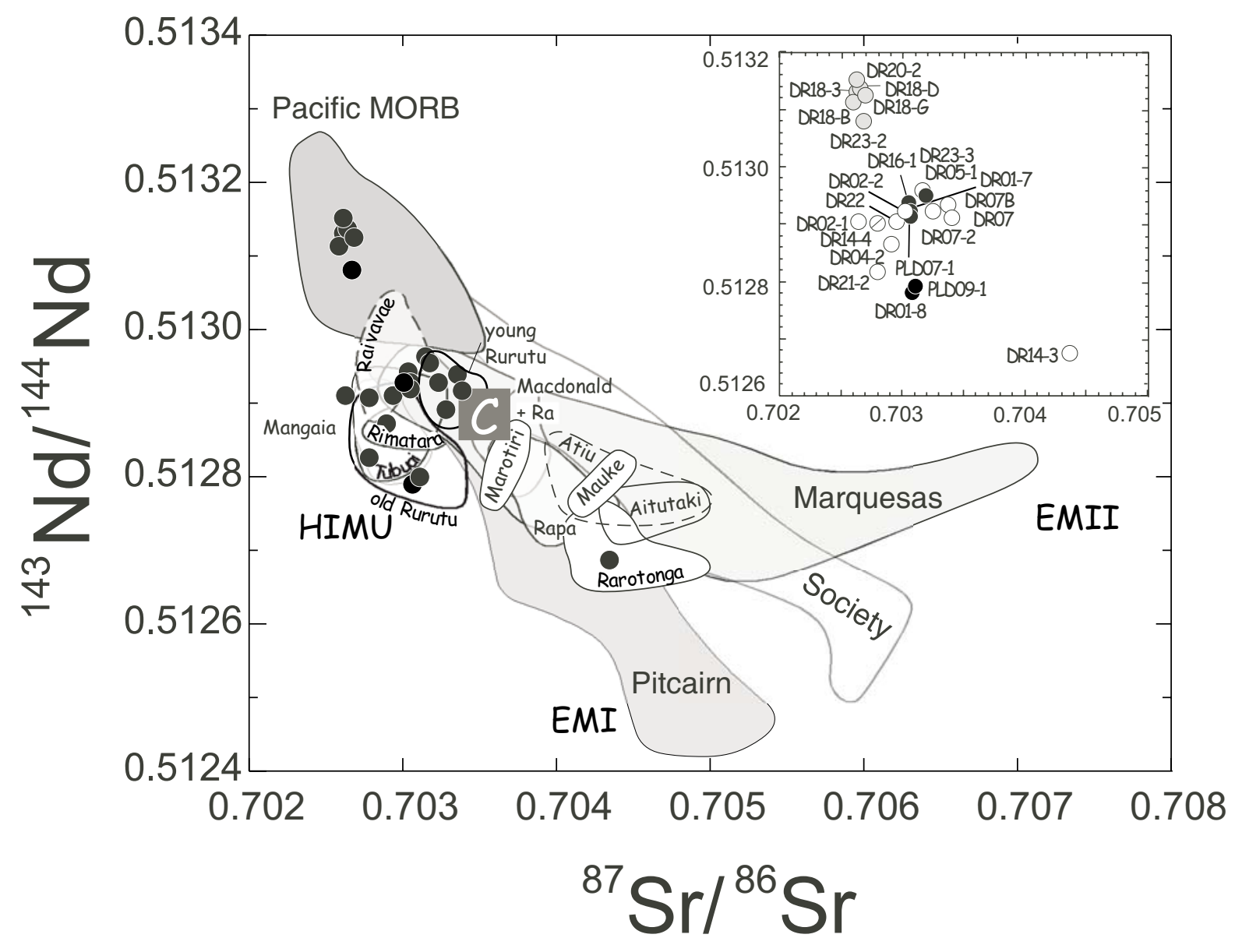

Figure 7

Bonneville et al., 2005 

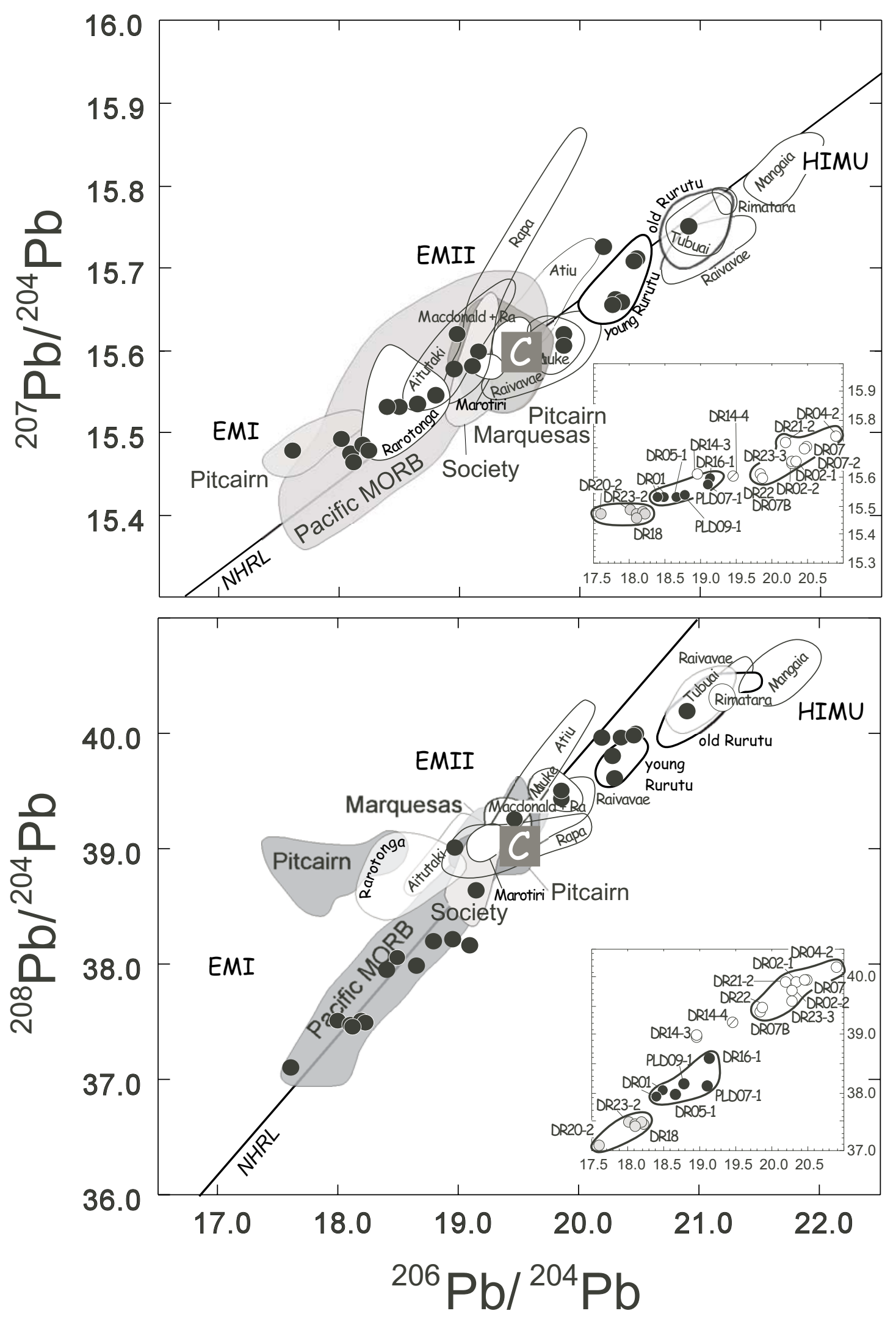

Figure 8

Bonneville et al., 2005 

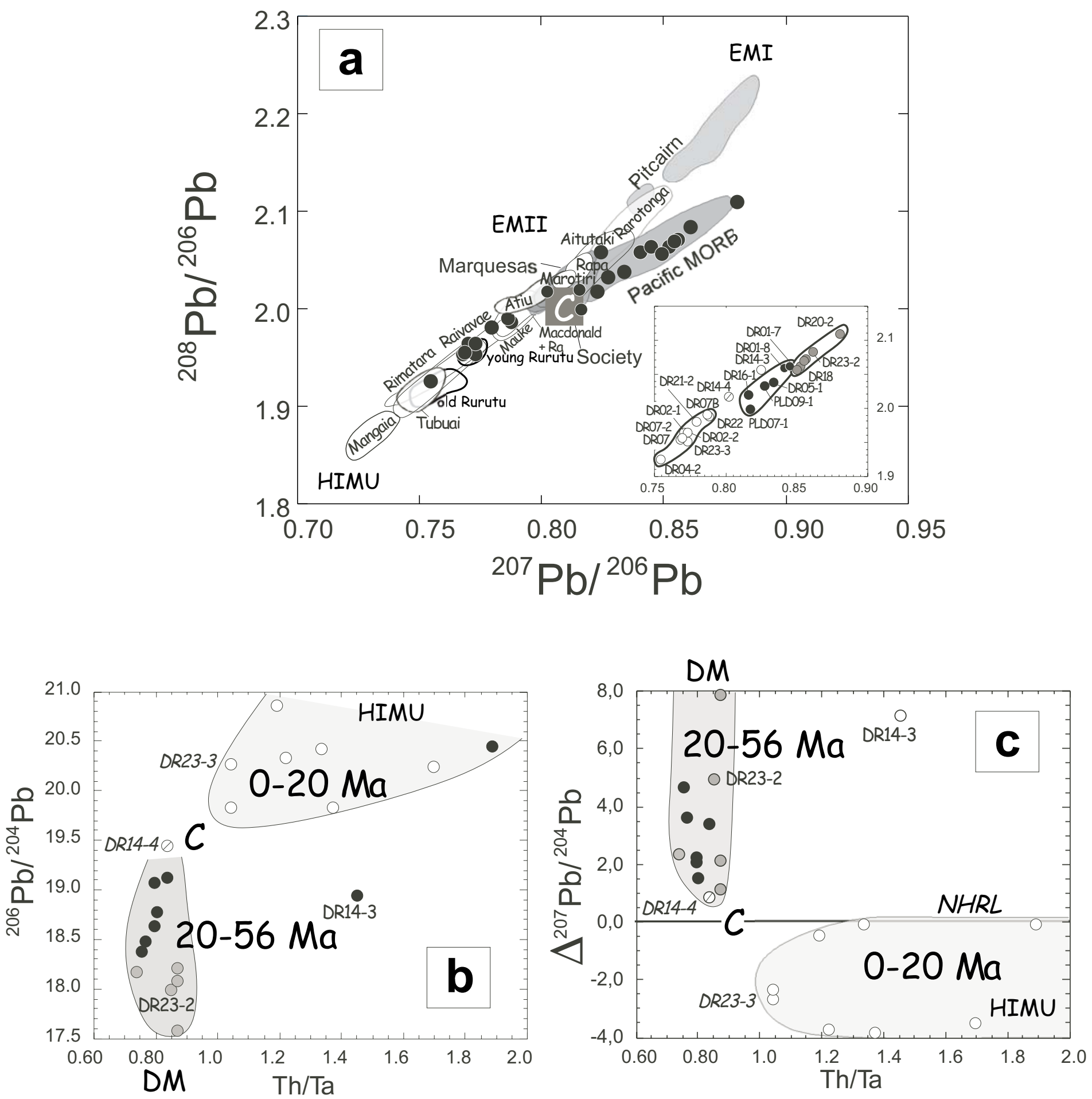

Figure 9

Bonneville et al., 2005 


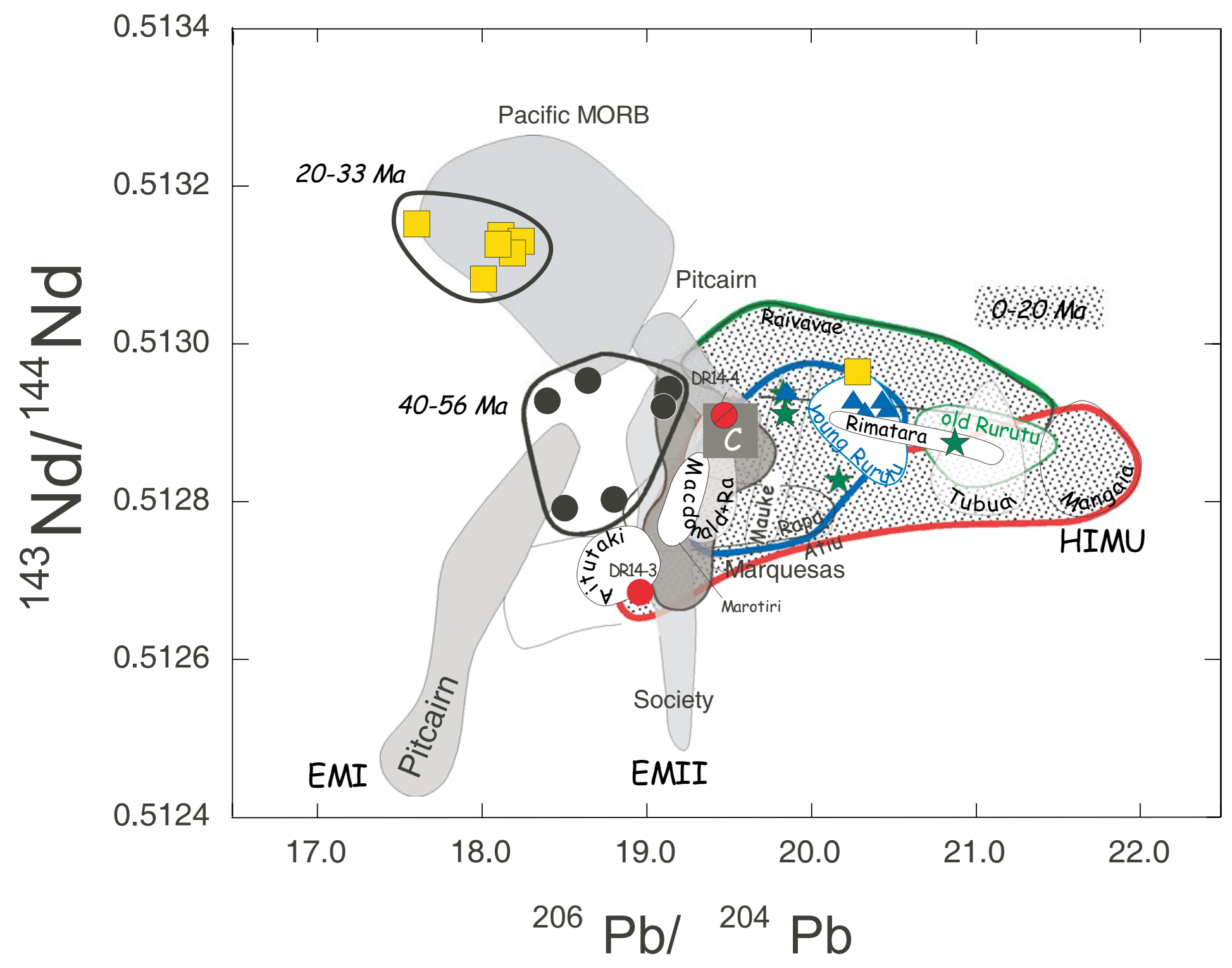

Figure 10

Bonneville et al., 2005 


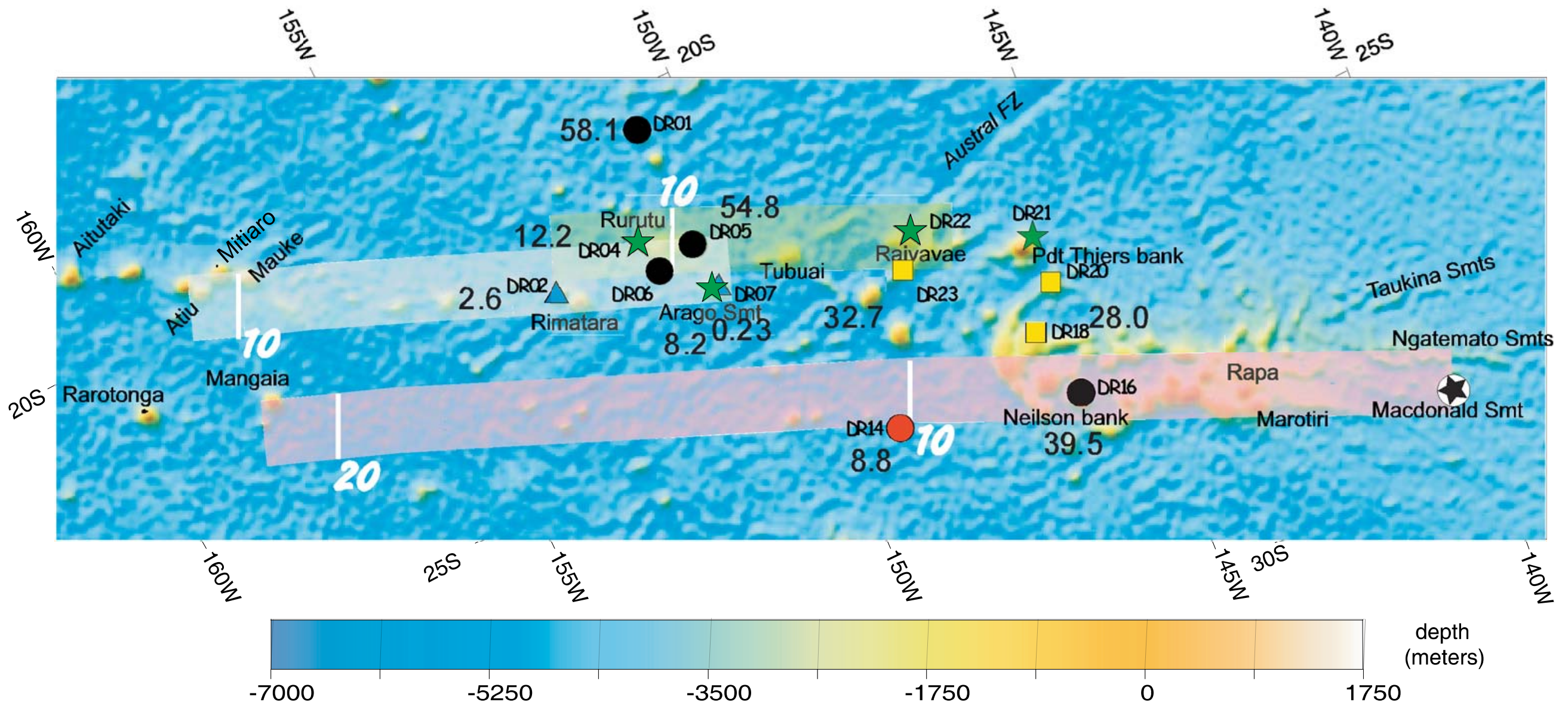

Figure 11

Bonneville et al., 2005 